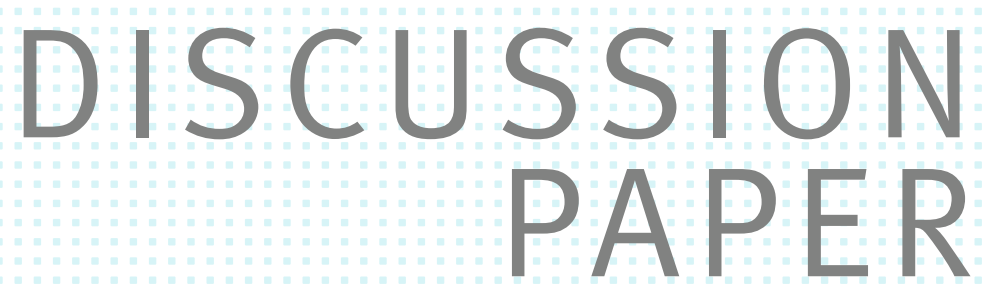

// CHRISTOPH SPENGEL, LEONIE FISCHER, AND KATHRIN STUTZENBERGER

\title{
Breaking Borders? \\ The European Court of Justice and Internal Market
}




\title{
Breaking Borders?
}

\section{The European Court of Justice and Internal Market}

\author{
Christoph Spengel \\ (University of Mannheim/Leibniz Centre for European Economic Research (ZEW)) \\ Leonie Fischer \\ (ZEW/University of Mannheim) \\ Kathrin Stutzenberger \\ (University of Mannheim)
}

This version: 9 November 2020

\begin{abstract}
Upon more than 400 judgements on direct taxation, the case law of the European Court of Justice has considerably shaped Member States' tax systems. Based on Member States' tax law adjustments in the context of four landmark rulings on corporate income taxation, we analyse whether case law is a suitable instrument to eliminate tax distortions towards the realisation of a European internal market. Our analysis is based on effective tax burdens using the Devereux/Griffith methodology. Overall, we find that due to Member States' mostly heterogeneous adjustments and varying levels of compliance, cross-border investment continues to be discriminated in some Member States following the Marks \& Spencer and National Grid Indus judgements. In addition, differences in the general availability of the rules under scrutiny and design of related provisions, cross-country differences in effective tax burdens and hence distortions to the internal market might persist. We conclude that a comprehensive harmonisation of Member States' tax systems by way of positive integration would be necessary to sustainably eliminate tax obstacles to cross-border business activities.
\end{abstract}

\section{JEL classification: H25, K34}

Keywords: European Court of Justice, Internal Market, Effective Tax Rates, Thin Capitalisation Rules, Cross-Border Loss Relief, Controlled Foreign Company Rules, Exit Taxation

Acknowledgements: We gratefully acknowledge support from the MannheimTaxation Science Campus, funded by the Leibniz Association, the state of Baden-Württemberg, and the participating institutions ZEW and University of Mannheim. Moreover, we would like to thank Rainer Bräutigam, Michael P. Devereux, Jost H. Heckemeyer, Katharina Nicolay, Alice Pirlot, Daniela Steinbrenner, the participants of the Oxford University Centre for Business Taxation's Brownbag Seminar, of the Brownbag Seminar Accounting \& Taxation at the University of Mannheim and of the University of Mannheim and University of Brescia's joint workshop for many valuable comments as well as Peter Buchmann for technical support. Part of this research was conducted while Kathrin Stutzenberger was visiting at the Oxford University Centre for Business Taxation with a mobility grant funded by the University of Mannheim's "Women go abroad" programme. Responsibility for errors remains the authors'. 


\section{Introduction}

The European Union (EU) does not have any mandate to harmonise direct taxes across Member States. Therefore, case law of the European Court of Justice (ECJ) has become a decisive determinant for the development of European tax systems and European integration. ${ }^{1}$ As of 2019, the ECJ has decided around 400 cases on Member States' rules for direct taxation. ${ }^{2}$ In its landmark "Avoir Fiscal"3 judgement of 1986, the ECJ established that - despite their sovereignty in the field of direct taxes - Member States must not infringe the fundamental freedoms. ${ }^{4}$ Following this judgement, ECJ case law "has gained both momentum and significance". ${ }^{5}$ As such, it contributes to the long-term objective of the EU regarding the establishment of an internal market in terms of an "area without internal frontiers" that features, among others, "free competition" as well as "an efficient allocation of resources" (Art. 26 (2), 120 of the Treaty on the Functioning of the European Union (TFEU)). ${ }^{6}$ The realisation of the internal market is thus contingent on the four fundamental freedoms (free movement of capital, goods, labour and services) as well as on the prohibition of cartel agreements, State aid or misuse of market power. ${ }^{7}$

The legal impact of ECJ case law has been subject to detailed studies: On the one hand, legal literature includes numerous detailed discussions of single rulings and their implications for the tax laws of the affected Member States. ${ }^{8}$ These considerations, however, are predominantly limited to the Member States that are directly affected by a particular ruling and exclude potential adjustments that have likewise been adopted in other Member States. ${ }^{9}$ On the other hand, legal literature analyses the development of European judicature in different fields of tax law. ${ }^{10}$ In contrast, evidence on the economic impact of case law on, for example, investment conditions or Member States' location attractiveness is comparatively scarce: ${ }^{11}$ For instance, Bräutigam et al. (2017) analyse the implications of the ECJ's decision in the Cadbury

See Panayi (2010), p. 267.

See European Commission (2018) for a list of cases in the field of direct taxation.

ECJ, 28 January 1986, Case 270/83, Commission of the European Communities v French Republic ("Avoir Fiscal").

4 See Lazarov (2018), p. 63, para. 195.

5 See de la Feria/Fuest (2016), p. 53.

6 See also Bräutigam et al. (2017), p. 720.

7 See Adamczyk/Majdańska (2018), pp. 2 f., para 3.

8 Among many others, see, for instance, Gutmann/Hinnekens (2003); Vinther/Werlauff (2003); Hintsanen/Pettersson (2005).

9 A case study edited by Brokelind, however, provides a comprehensive overview on "how domestic courts, tax authorities and legislators cope with their duty to apply Community law, and especially, the ECJ's case law in the field of direct taxation", see Brokelind (2007), p. 7. Although information is reported on a country basis, the findings are ultimately consolidated towards an overall evaluation across Member States.

10 Among many others, see, for instance, Lang (2005); Lang (2014); Sendetska (2014); Cordewener (2018); Kraft (2018).

11 See also Bräutigam et al. (2017), p. 721. 
Schweppes case and resulting limited applicability of controlled foreign company (CFC) rules for tax competition and neutrality in Europe. In addition to potential adjustments of Member States' CFC rules, the authors include second round reactions where certain Member States implement special low-tax regimes for income from acquired intellectual property (so-called patent or IP box regimes). They consider different scenarios for the (in-) applicability of CFC rules and availability of patent box regimes and find that the Cadbury Schweppes ruling might have induced new distortions to cross-border tax neutrality in Europe. Besides, de la $\mathrm{Fe}$ ria/Fuest (2016) analyse the economic effects of Member States' reactions to the LankhorstHohorst judgement on thin capitalisation rules based on a theoretical model. In light of varying tax levels across Member States and different reactions to the ECJ's judgement, the authors conclude that tax distortions in the internal market might further increase. ${ }^{12}$ Schaper (2014a) reviews general trends in ECJ case law on direct taxation between 1983 and 2013 based on aggregated metadata, for instance regarding timing, geographical representation or subject matter. Furthermore, Schaper (2014b) identifies dominant judicial rules from the most important precedents in ECJ case law on direct taxation based on network analysis. Finally, Kube et al. (2016) conduct an interdisciplinary analysis and reflect on the past and future development of direct and indirect European tax law in order to derive implications for future direct tax policy. They suggest reinforcing negative integration and propose options for informal cooperation.

So far, the economic impact of ECJ case law has only been evaluated on the basis of single judgments. Hence, none of the above-mentioned studies analyses the economic consequences of ECJ case law for the realisation of a European internal market in a more systematic and broader way, for example by evaluating several rulings across different areas of case law on direct taxation. Furthermore, there is only little evidence on how ECJ case law affects investors' location decisions. This question is of high relevance since Member States' tax law adjustments in the context of ECJ case law can affect the tax environment for corporate investments in the EU.

Our paper contributes to the aforementioned interdisciplinary literature and intends to address the identified research gaps. The aim of the paper is twofold: In a first step, we investigate whether the judgements of the ECJ and Member States' related tax law adjustments to the enhanced standards from the judgement have succeeded to eliminate tax-induced discriminations

12 In a prior working paper, the authors further considered the economic effects of reactions to the Marks \& Spencer case regarding cross-border group loss consolidation. Since many Member States did not adjust their tax laws in response to that ruling, however, evidence on the economic effects of the Marks \& Spencer case is ambiguous. See de la Feria/Fuest (2011), pp. 40, 46 f. 
of cross-border investments in line with the mandate of the ECJ (qualitative analysis). In a second step and beyond the mandate of the ECJ, we evaluate the impact of Member States' tax law adjustments on investment conditions in the internal market (quantitative analysis). To this end, we conduct a case study analysis on the effects of four landmark ECJ decisions that concern different subareas of corporate taxation based on the effective average tax rate (EATR) determined according to the well-established Devereux/Griffith methodology for calculating forward-looking effective tax rates. We quantify how the four landmark decisions affect tax incentives in terms of EATR. This is a relevant measure because differences in EATR reveal investment distortions in the context of location choices.

Overall, we find that apart from several Member States' maintenance of discriminatory regulations after the judgment in the Marks \& Spencer and National Grid Indus cases, the ECJ seems to fulfill its mandate and achieves an equal tax treatment of domestic and cross-border investment choices. As such, the case law and Member States amendments to their tax laws contribute to eliminating tax distortions to investment choices between domestic and cross-border investments from the perspective of single Member States. To align their national rules with the enhanced requirements established by ECJ case law, Member States can generally adapt their rules in various ways. Due to heterogeneous adjustments, partly high levels of non-compliance as well as differences in the general availability of the rules under scrutiny across Member States, however, different country-specific outcomes in terms of EATR across Member States might even increase divergences in tax levels and hence tax distortions to investment location decisions in the EU. Therefore, a comprehensive harmonisation of Member States' tax rules by means of directives (positive integration) seems necessary to realise an internal market without tax distortions to investment.

The remainder of this paper proceeds as follows. In Section 2, we introduce the ECJ's approach towards the elimination of tax obstacles to cross-border business activities and the realisation of the internal market. In Section 3, we present the Devereux/Griffith model as the underlying methodological framework for the subsequent analyses of the implications of Member States' adjustments to selected case law for the realisation of the internal market. In Sections 4 to 7 , we first introduce the particular case under consideration and - if necessary - potential adjustments to the Devereux/Griffith model framework to reflect the distinctive features of the rules in question. Subsequently, we present and classify Member States' potential amendments to their tax legislation in the context of the case under consideration. As a last step, we quantify the related tax effects and discuss the implications for the realisation of the internal market 
based on (otherwise fixed) country tax data of the year preceding the year when the judgement under consideration was given. In particular, we consider landmark cases in the context of thin capitalisation rules (Lankhorst-Hohorst decision, Section 4), intra-group loss relief (Marks \& Spencer decision, Section 5), CFC rules (Cadbury Schweppes decision, Section 6) and exit taxation (National Grid Indus decision, Section 7). Considerations are limited to EU Member States at the time of the ruling, respectively. Section 8 concludes.

\section{European Court of Justice and its Approach towards the Realisation of the Common Market}

The foundation of the European Economic Community (EEC) by the Treaty of Rome in 1957 envisaged the establishment of a common market in terms of common tariffs and other policies as well as the elimination of any other obstacles to cross-border trade. ${ }^{13}$ Upon the approval of the Single European Act (SEA) in 1987, the concept of the internal market was introduced to clarify the concept of a common market. ${ }^{14}$ According to Article 26 (2) TFEU, the internal market is defined as an "area without internal frontiers in which the free movement of goods, persons, services and capital is ensured in accordance with the provisions of the Treaties". As such, the fundamental freedoms are essential for the realisation of the internal market. ${ }^{15}$

To achieve an internal market, two complimentary strategies exist that build on a different institutional approach: ${ }^{16}$ On the one hand, positive integration "follows the legislative process"17 and relies on the implementation of harmonised common policies across Member States. ${ }^{18}$ Any measure adopted under positive integration shapes the development of the internal market ${ }^{19}$ based on "explicit political legitimation". ${ }^{20}$ As such, positive integration aims at policy integration including the introduction of common policies and the approximation of laws. ${ }^{21}$ On the other hand, negative integration contributes to the liberalisation of markets by eliminating competitive distortions ${ }^{22}$ and hence strives for the "abolition of [...] impediments to the proper operation of an integrated area". ${ }^{23}$ Negative integration is usually enforced through the "decisions

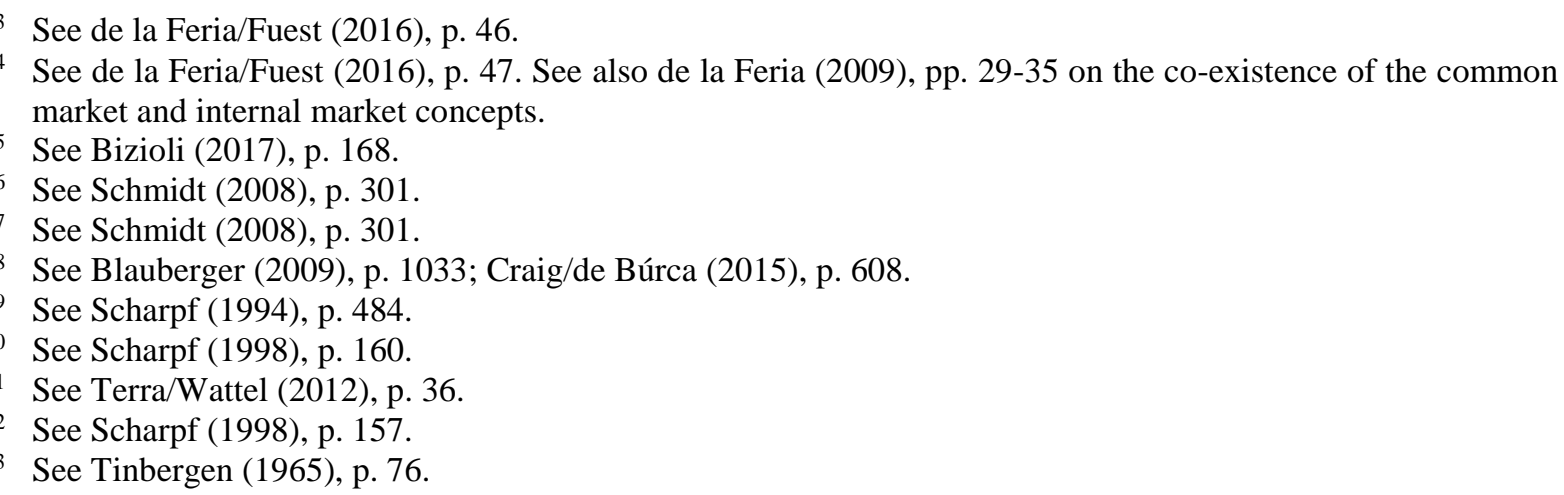


and case law of the [European] Commission and [ECJ]". ${ }^{24}$ Positive and negative integration jointly achieve economic integration with the overall objective to realise an economic union. ${ }^{25}$ According to Article 114 TFEU, the European Parliament and Council may adopt measures to harmonise Member States' national laws in case this ensures the establishment and functioning of the internal market. More precisely, the harmonisation mandate is limited to areas where divergences in Member States' respective tax rules obstruct the functioning of the internal market. ${ }^{26}$ However, according to Article 115 TFEU, any such legislative measure requires Member States' unanimous consent. In contrast to indirect taxes where Article 113 TFEU provides an explicit legal basis for harmonisation, ${ }^{27}$ among others, Member States' hesitance to limit their sovereignty on direct tax matters and the unanimity requirement have inhibited major advances regarding the harmonisation of direct taxes. ${ }^{28}$ Hence, consensus for measures of positive integration seems easier to achieve "in policy areas where national interests converge". ${ }^{29}$ To date, harmonised legislation on direct tax matters is still scarce ${ }^{30}$ and includes the Parent-Subsidiary Directive (2011/96/EU), ${ }^{31}$ the Merger Directive $(2009 / 133 / \mathrm{EC})^{32}$ as well as the Interest and Royalties Directive (2003/49/EC). ${ }^{33}$ More recently - and within a record six months negotiation period - the Anti-Tax Avoidance Directive (ATAD I and II; 2016/1164/EU and 2017/952/EU) ${ }^{34}$ was approved in July 2016 with the aim to transpose the results of the OECD's Base Erosion and Profit Shifting (BEPS) project into Member States' corporate income tax codes. However, it has been criticised that the resulting harmonisation was selective $\mathrm{e}^{35}$ and that the underlying measures would not "promot[e] a common system of direct taxation". ${ }^{36}$ So far, Member States

24 See Schmidt (2008), p. 301.

25 See Pinder (1968), p. 90.

26 See Terra/Wattel (2012), p. 3.

27 See, for instance, Kube et al. (2016), pp. $248 \mathrm{f}$. for the development of indirect tax harmonisation among Member States.

28 See Terra/Wattel (2012), p. 37; de la Feria/Fuest (2016), pp. 51 f.

29 See Scharpf (2006), p. 855.

30 See also Blum/Langer (2019), p. 285 for an overview of enacted and potential future legislation on direct taxes. A detailed overview of direct tax harmonisation is also provided in Kube et al. (2016), pp. 249-251.

31 Council Directive 2011/96/EU of 30 November 2011 on the common system of taxation applicable in the case of parent companies and subsidiaries of different Member States, OJ L 345/8 (29.12.2011).

32 Council Directive 2009/113/EC of 19 October 2009 on the common system of taxation applicable to mergers, divisions, partial divisions, transfers of assets and exchanges of shares concerning companies of different Member States and to the transfer of the registered office of an SE or SCE between Member States, OJ L 310/34 (25.11.2009).

33 Council Directive 2003/49/EC of 3 June 2003 on a common system of taxation applicable to interest and royalty payments made between associated companies of different Member States, OJ L 157/49 (26.6.2003).

34 Council Directive (EU) 2016/1164 of 12 July 2016 laying down rules against tax avoidance practices that directly affect the functioning of the internal market, OJ L 193/1 (19.7.2016); Council Directive (EU) 2017/952 of 29 May 2017 amending Directive (EU) 2016/1164 as regards hybrid mismatches with third countries, OJ L 144/1 (7.6.2017).

35 See also Seiler (2005), p. 26.

36 See Aujean (2010), p. 16. 
could not find consensus on far-reaching harmonisation concepts such as the introduction of a Common (Consolidated) Corporate Tax Base (C(C)CTB). ${ }^{37}$

For lack of a comprehensive harmonisation of direct taxation by means of positive integration, the ECJ holds an important "constitutional mandate to ensure the establishment of a European internal market" in terms of fiscal neutrality and a level playing-field. ${ }^{38}$ The ECJ's approach of negative integration relies on market integration and constrains Member States' tax sovereignty. ${ }^{39}$ To identify an unlawful discrimination or restriction of a fundamental freedom, the ECJ applies a transaction-based approach and compares the treatment of domestic and crossborder investments. ${ }^{40}$ As such, ECJ case law might encourage both capital export neutrality (CEN) and capital import neutrality (CIN) among Member States to establish investment and financing neutrality. ${ }^{41}$ Under a tax system that satisfies CEN, an investor is taxed equally irrespective of the actual location where the investment is conducted. In line with CIN, by contrast, inbound investment is taxed independent of the actual residence country of the investor.

If the ECJ holds a domestic rule incompatible with EU law, Member States can generally amend their tax laws in several different ways to ensure an equal treatment of domestic and crossborder investment in line with the fundamental freedoms. ${ }^{42}$ On the one hand, they could extend a favourable domestic tax treatment to intra-EU cross-border cases and thus limit the applicability of a discriminatory rule to cross-border cases with third countries. On the other hand, Member States could extend the scope of a discriminatory rule to cover also domestic cases. Besides, Member States could abolish the rule in question whereas they could likewise decide to maintain a rule that infringes EU law (non-compliant strategy).

\section{Methodology: Devereux/Griffith Model}

To estimate the impact of ECJ case law on the effective tax burden of firms situated in different Member States and its contribution to eliminating tax distortions to the internal market, we follow the well-established Devereux/Griffith methodology $(1999,2003) .{ }^{43}$ The model builds

37 See European Commission (2011) for the original as well as European Commission (2016a) and European Commission (2016b) for the re-launched proposals. See also de la Feria/Fuest (2016), p. 52; Kube et al. (2016), p. 253.

38 See de la Feria/Fuest (2016), p. 45.

39 See Terra/Wattel (2012), pp. $35 \mathrm{f}$.

40 See Schreiber/Führich (2009), p. 259.

41 See Schreiber/Führich (2009), pp. 258 f. For a detailed description of CEN and CIN as well as a discussion in the context of ECJ case law, see also Spengel (2003), pp. 257-259; Terra/Wattel (2012), pp. 210-222; Bräutigam et al. (2017), pp. 723-725.

42 See also de la Feria/Fuest (2011), pp. 23, 35; de la Feria/Fuest (2016), p. 57 for the different types of reaction.

43 For a detailed description of the model framework, see also Spengel (2003), pp. 68-77; Spengel et al. (2018a), pp. 171-174. The model has been used in various prior studies, see, for instance, Evers et al. (2015); Spengel/Bergner (2015); Spengel et al. (2016a); Spengel et al. (2016b); Spengel et al. (2016c); Bräutigam et al. 
on neoclassical investment theory and assumes a perfect capital market under certainty as well as successful real investment. ${ }^{44}$ The basic approach proposed by Devereux and Griffith considers a hypothetical domestic incremental investment either by a resident or non-resident company. This investment takes place in one period and generates a return during the next period. To analyse the effect of taxes on the return of the incremental investment, the model incorporates country-specific information on the type of tax system, types of applicable taxes (profit/non-profit), tax bases and tax rates on company and investor level. ${ }^{45}$

The model distinguishes between marginal investments that just yield the minimum required return (relevant measures: effective marginal tax rate (EMTR) and cost of capital (CoC)) and profitable investments that earn economic rents (relevant measure: EATR). ${ }^{46}$ For purposes of this paper, we only consider the EATR with the aim to evaluate the impact of taxes on discrete location choices. More precisely, we aim to ascertain whether ECJ case law contributes to eliminating tax distortions to corporate investment location decisions across Member States.

The EATR indicates the tax-induced reduction of the net present value (NPV) of profitable investment. From the perspective of an investor, a lower EATR for an investment alternative generally signals a higher attractiveness of the investment/location. ${ }^{47}$ It is computed as the difference of NPV before and after taxes (denoted by $R^{*}$ and $R$ ), divided by the discounted pretax rate of return $p$ :

(1) $E A T R=\frac{R^{*}-R}{p /(1+r)}$

Alternatively, the EATR can be written as: ${ }^{48}$

(2) $E A T R=\frac{\tilde{p}}{p} * E M T R+\frac{p-\tilde{p}}{p} * \tau$

In this case, the EATR corresponds to the EMTR if the pre-tax rate of return $p$ equals the cost of capital $\tilde{p}$. Upon increasing profitability, i.e. an increasing pre-tax rate of return, the EATR approaches the corporate income tax rate $\tau$. Hence, the EATR is mainly driven by the corporate

(2017); Pfeiffer/Spengel (2017); Spengel et al. (2018b) as well as the ZEW's annual update on EU effective tax levels. For the latest update, see ZEW (2018).

44 See Evers et al. (2015), p. 510; Pfeiffer/Spengel (2017), p. 21.

45 As indicated by the annual update on effective tax levels in the EU; see ZEW (2018).

46 See also Bergner (2017), pp. 200 f.; Olbert et al. (2019), p. 152.

47 For a simplifying illustrative example and interpretation, see Spengel et al. (2018b), p. 62; Spengel et al. (2018a), p. 173.

48 Personal taxes are neglected. See, for instance, Spengel et al. (2016c), p. 16 and for the derivation Devereux/Griffith (1999), pp. $21 \mathrm{f}$. 
income tax rate whereas the impact of tax base elements considerably diminishes for such investments. $^{49}$

We provide for a detailed description of the basic formulas of the Devereux/Griffith model as well as the underlying economic assumptions in Appendix A.1.

In all subsequent sections, the economic effects of the particular case under consideration are evaluated separately based on country tax data of the year prior to the ruling to avoid any confounding effects from potential tax law changes in anticipation of the judgement. As such, all elements of the tax code remain fixed and only the particular rule under consideration is adjusted if Member States amend their laws in the context of the case ${ }^{50}$ Considerations are further limited to those countries that were part of the EU during that particular year and are thus subject to mandatory compliance with ECJ case law. ${ }^{51}$

We evaluate the realisation of the internal market based on two perspectives: First, as a benchmark for discrimination of cross-border investment, we consider a comparable domestic investment to determine a potential discrimination at country level. If the EATR of cross-border investment is higher than the EATR of domestic investment, domestic investment would be preferred which obstructs the realisation of the internal market from the perspective of the respective Member State. Upon an equal treatment of domestic and cross-border investment, the ECJ has fulfilled its mandate to ensure a non-discriminatory treatment of cross-border investment.

Subsequently and in line with prior similar analyses, we consider both the mean and standard deviation of effective tax burdens across Member States before and after a particular judgement was rendered. ${ }^{52}$ As such, a declining cross-country spread in EATR might indicate a stronger alignment of tax burdens across Member States as well as a related elimination of tax distortions to investment location decisions towards the realisation of the internal market. ${ }^{53}$

49 See Devereux/Griffith (2003), pp. 112 f.; Spengel (2003), pp. 75 f.; Spengel et al. (2016c), p. 16.

50 Information on Member States' potential tax law adjustments in the context of the respective judgements is derived from own research in the annual European tax handbooks published by the International Bureau of Fiscal Documentation (IBFD) and the IBFD's online tax research platform (https://www.ibfd.org/). The judgement under consideration is not necessarily (exclusively) causal for the amendments of Member States' tax laws. Apart from being explicitly mentioned as one of the causes, we further assume that a legislative change (amongst others) relates to a particular judgement if it occurs the judgement's immediate (temporal) context.

51 Estonia applies a special corporate income tax system where only distributed profits are subject to tax while retained profits are tax exempt. As such, the Estonian corporate income tax code does not include any rules for the determination of taxable income. Hence, Estonia is only considered where suitable in the following subsections, as most of the ECJ's case law under consideration in this study would not have any impact.

52 See Bräutigam et al. (2017), pp. 722, 732 who further refer to Devereux/Pearson (1995) and Elschner et al. (2011). Similarly, de la Feria/Fuest (2016), pp. 58-65, 71 consider differences in capital costs.

53 Our results might reflect the upper bound of the changes in EATR for investments that yield a higher pre-tax rate of return as specified in the Devereux/Griffith model and vice versa. Still, they are of high relevance for 


\section{Interest Deduction Limitation Rules and the "Lankhorst-Hohorst" Case}

\subsection{Case setting and preliminary remarks}

The "Lankhorst-Hohorst" case (C-324/00) ${ }^{54}$ was one of the first rulings on the conformity of national thin capitalisation rules with EU law ${ }^{55}$ and hence constitutes one of the Court's landmark decisions. ${ }^{56}$ In the case at hand, Lankhorst-Hohorst $\mathrm{GmbH}$, a German thinly capitalised corporation, received a loan from its Dutch grandparent that waived its claims for repayment in a related letter of support if claims by third parties existed. ${ }^{57}$ According to the former German thin capitalisation rules, interest payments on loans granted to a German resident corporation by a shareholder that was not entitled to a German corporation tax credit (typically a non-resident shareholder) were treated as a covert profit distribution if interest was calculated as a percentage of the loan and the debt-to-equity ratio exceeded a threshold of $3: 1{ }^{58}$ However, there was no re-characterisation of deductible interest as a non-deductible deemed dividend if the loan was provided under arm's length conditions, i.e. if an independent third party would have granted the loan under similar conditions. ${ }^{59}$ In contrast, interest was fully deductible irrespective of the underlying debt/equity ratio if paid to a domestic parent. ${ }^{60}$ Due to the high debt-toequity ratio of Lankhorst-Hohorst $\mathrm{GmbH}$ and the related lack of securities that could have been provided to an external lender, German tax authorities treated the interest paid to the Dutch grandparent as a non-deductible covert profit distribution. ${ }^{61}$ In its ruling of 12 December 2002, the ECJ concluded that German thin capitalisation rules discriminated against inbound investment which was held incompatible with the freedom of establishment (Art. 43 EC). ${ }^{62}$

the policy debate since they nevertheless indicate whether it is possible to reduce tax distortions to investment location decisions among Member States.

54 ECJ, 12 December 2002, Case C-324/00, Lankhorst-Hohorst GmbH v Finanzamt Steinfurt.

55 See Gutmann/Hinnekens (2003), p. 90.

56 See de la Feria/Fuest (2016), p. 57.

57 See Lankhorst-Hohorst (C-324/00), para. 5-25 for the case setting and prior legal procedure.

58 See Lankhorst-Hohorst (C-324/00), para. 3 for a brief overview of the underlying legislation.

59 See Lankhorst-Hohorst (C-324/00), para. 3; Thoemmes et al. (2004), p. 127.

60 See Lankhorst-Hohorst (C-324/00), para. 27-29.

61 See Lankhorst-Hohorst (C-324/00), para. 11-12.

62 See Lankhorst-Hohorst (C-324/00), para. 45. For a detailed legal description and discussion of the case, see, for instance, Gutmann/Hinnekens (2003). 
In Section 4.3., we analyse the effects of the Lankhorst-Hohorst case from the perspective of a corporation that pays interest either to a domestic or to a foreign investor based on the reference year 2001. All country-specific criteria for the applicability of interest deduction limitation rules are held fulfilled. If a Member State restricts the deductibility of domestic and/or cross-border interest payments by whichever rule, we assume that such rules fully inhibit interest deductibility and hence, increase the EATR (c.p.). We present the methodology in more detail in Appendix A.2.1. Unlike prior studies, our considerations also include rules that apply only among related parties which was quite common among Member States at the time of the LankhorstHohorst case.

\subsection{Member States' tax law adjustments in the context of the case}

In Table 1, we provide an overview of the scope and availability of thin capitalisation rules across the EU-15 Member States before and after the ruling in the Lankhorst-Hohorst case. ${ }^{63}$ Prior to the judgement, eight out of 15 countries under consideration restricted the deductibility of interest payments on intra-group loans from foreign shareholders. In this context, Belgium is the only country where the scope of the thin capitalisation rule also included interest payments to a domestic lender. Member States' tax law adjustments in the context of the LankhorstHohorst judgement were quite heterogeneous: Four Member States excluded intra-EU situations from the scope of their thin capitalisation rules whereas three countries extended the interest deduction limitation on intra-group loans also to domestic shareholders. Besides, Italy and the Netherlands newly introduced thin capitalisation rules in $2004 .{ }^{64}$ Especially in the case of Italy, the ECJ's ruling in the Lankhorst-Hohorst case had a remarkable impact on the design of the regulation: Although the first draft bill excluded purely domestic situations from the scope of the thin capitalisation rules, the regulation was amended during the legislative process to cover both foreign and domestic lenders in order to avoid concerns on the incompatibility of the new rules with EU law. ${ }^{65}$ Accordingly, all Member States have adjusted their existing thin capitalisation rules and have ensured compatibility with EU law following the LankhorstHohorst judgement.

63 The presentation of country practice follows the general presentation by de la Feria/Fuest (2011), p. 33; de la Feria/Fuest (2016), pp. 66 f. However, the classification of Member States' thin capitalisation rules partly deviates, which might be due to different assumptions with regard to the length of the period for Member States' potential adjustments and/or the underlying information sources. See also Dourado/de la Feria (2008), pp. 2-16 for the development of interest deduction limitation rules across Member States up to 2008.

64 See, for instance, Gusmeroli/Russo (2004) for the introduction of thin capitalisation rules in Italy. In the Netherlands, thin capitalisation rules were introduced following the ECJ's 2003 ruling in the "Bosal Holding BV" case (C-168/01); see Thoemmes et al. (2004), p. 127.

65 See Gusmeroli/Russo (2004), p. 513; Rossi (2005), p. 89. 


\begin{tabular}{|c|c|c|c|c|}
\hline & \multicolumn{4}{|c|}{ Scope of thin capitalisation rules } \\
\hline & \multicolumn{2}{|c|}{ Pre-Lankhorst-Hohorst } & \multicolumn{2}{|c|}{ Post-Lankhorst-Hohorst } \\
\hline & National & EU Member States & National & EU Member States \\
\hline AT & - & - & - & - \\
\hline $\mathrm{BE}$ & $\mathrm{x}$ & $\mathrm{x}$ & $\mathrm{x}$ & $\mathrm{x}$ \\
\hline $\mathrm{DE}$ & - & $\mathrm{x}$ & $\mathbf{x}$ & $\mathrm{x}$ \\
\hline DK & - & $\mathrm{x}$ & $\mathbf{x}$ & $\mathrm{x}$ \\
\hline EL & - & - & - & - \\
\hline ES & - & $\mathrm{x}$ & - & - \\
\hline FI & - & - & - & - \\
\hline FR & - & $\mathrm{x}$ & - & - \\
\hline IE & - & $\mathrm{x}$ & - & - \\
\hline IT & - & - & $\mathbf{x}$ & $\mathbf{x}$ \\
\hline $\mathrm{LU}^{66}$ & - & - & - & - \\
\hline NL & - & - & $\mathbf{x}$ & $\mathbf{x}$ \\
\hline PT & - & $\mathrm{x}$ & - & - \\
\hline SE & - & - & - & - \\
\hline $\mathrm{UK}^{67}$ & - & $\mathrm{x}$ & $\mathbf{x}$ & $\mathrm{x}$ \\
\hline $\begin{array}{l}\text { thin cal } \\
\text { hin cap }\end{array}$ & $\begin{array}{l}\text { rules ava } \\
\text { rules not }\end{array}$ & & & \\
\hline
\end{tabular}

\subsection{Implications of the "Lankhorst-Hohorst" case for the realisation of the internal market}

In Table 2, we illustrate the EATR for a debt-financed investment of a corporation that pays interest either to a domestic or to a foreign lender before and after the Lankhorst-Hohorst ruling, respectively. The depicted values represent the combined tax burdens including the taxation at the level of the domestic or foreign lender. For the cross-border case, we consider all possible foreign lenders situated in any other EU-15 Member State. However, for the sake of clarity, Table 2 only includes the lender combination that yields the lowest and highest cross-border EATR for each interest paying entity resident in a particular Member State, respectively.

Before the ECJ rendered its decision in the Lankhorst-Hohorst case, the unweighted average EATR for domestic loan arrangements is at $31.95 \%$ across Member States. The standard deviation at 10.06 indicates a comparatively high cross-country spread in EATR. Upon lending from a foreign investor, the average lowest EATR at $31.31 \%$ is similar to the average EATR

66 In Luxembourg, interest deductibility is limited by administrative practice rather than codified national rules. As this approach does not represent a thin capitalisation rule in the strict sense, it is classified as the general absence of thin capitalisation rules.

67 As of 1 April 2004, the United Kingdom's thin capitalisation rules form part of the extended transfer pricing regime. We classify this as general availability of thin capitalisation rules due to the related legal codification. 
for domestic lending whereas the average highest EATR is considerably higher (at $43.83 \%$ ). The cross-country spread in EATR as measured by the standard deviation is equally quite high. Due to differences in the availability and scope of thin capitalisation rules, the consideration of country-specific EATR reveals important divergences in the treatment of domestic and crosscountry interest payments. Corporations resident in Member States that do not apply any thin capitalisation rules (Austria, Finland, Greece, Italy, Luxembourg, Netherlands, Sweden) tend to have an incentive to shift taxable profits to low-tax countries through tax-deductible interest payments as a lower overall EATR can be achieved than in case of domestic intra-group lending. Before Member States have adjusted their thin capitalisation rules to ensure compliance with the Lankhorst-Hohorst judgement, cross-border investment was discriminated in Denmark, France, Germany, Ireland, Portugal and the United Kingdom. ${ }^{68}$

Member States' amendments to their thin capitalisation rules following the Lankhorst-Hohorst decision align the treatment of domestic and cross-border interest payments and hence avoid any discrimination of cross-border investment. In all Member States except Ireland, the EATR of cross-border lending is (in part considerably) lower than for domestic lending which induces a preference for cross-border loan arrangements if the aim is to lower the overall tax burden of the group. However, depending on the underlying type of adjustment, the causes for the changes in preferences differ. In countries such as Germany, Denmark or the United Kingdom where the scope of thin capitalisation rules was extended to include domestic interest payments, the EATR for domestic intra-group lending increases and cross-border lending hence becomes the preferred investment choice. Other countries like France, Portugal and Spain limit the applicability of thin capitalisation rules to loan arrangements with third country residents. In consequence, the EATR for cross-border investment in part considerably decreases which reinforces the favourability of cross-border lending in order to minimise the group's overall EATR. Italy and the Netherlands newly introduced comprehensive thin capitalisation legislation following the Lankhorst-Hohorst case. As the rules cover both domestic and cross-border interest payments, the EATR of any form of intra-group lending increases. Since the EATR for cross-border lending remains lower than the EATR for domestic lending, the introduction of thin capitalisation rules does not seem to alter the existing preference for cross-border lending that followed from full interest deductibility before the Lankhorst-Hohorst decision. Overall, the ECJ

68 Since the Belgian thin capitalisation rule likewise covered domestic and cross-border interest payments already before the Lankhorst-Hohorst decision, there was no discrimination of cross-border investment. 
thus seems to fulfill its mandate in eliminating tax obstacles to cross-border economic activity at country level.

Only corporations resident in Ireland cannot decrease their tax burden below the level of domestic lending upon a cross-border loan arrangement and would hence prefer to obtain the loan from a domestic affiliate. Besides, the EATR of a Greek resident corporation would be lowest if it obtains the loan from a Swedish affiliate. For corporations resident in any other Member State, lending from an Irish affiliate is the preferred investment choice as it yields the lowest overall EATR after the Lankhorst-Hohorst judgement. ${ }^{69}$ As such, although Member States' tax law adjustments following the Lankhorst-Hohorst case contribute to eliminating tax discriminations to cross-border investment, the enhanced preference for cross-border debt financing might likewise contribute to intensifying tax rate competition for mobile investment capital among Member States. Besides, the spread in EATR for domestic lending increases upon the extended scope or introduction of thin capitalisation rules in five Member States (10.06 v 12.33) whereas the standard deviation for the lowest possible EATR slightly decreases for cross-border lending (9.18 v 8.55). Nevertheless, a remarkable divergence in (cross-border) EATR persists which continues to distort corporate investment location decisions.

Upon the mandatory application of the ATAD as of 1 January 2019, Member States must implement an interest deduction limitation rule in line with the earnings stripping rule established in Article 4 ATAD by 31 December $2018 .^{70}$ This rule covers both domestic and cross-border interest payments. As evident from the above analysis of extended interest deduction limitation rules that include interest paid to domestic shareholders following the Lankhorst-Hohorst case, the obligation to implement interest deduction limitation rules - ceteris paribus - increases EATR levels for both domestic and cross-border interest payments in the countries affected. ${ }^{71}$ Based on the above simplifying assumptions, this might contribute to a closer alignment of cross-country EATR.

69 Even if the preferred location of the foreign lender remains constant following Member States ' tax law adjustments to the Lankhorst-Hohorst decision, the underlying EATR might change. These changes trace back to changes in thin capitalisation rules in the residence countries of both the lessor and lender.

70 In case Member States already dispose of an "equally effective" interest deduction limitation rule, the transposition deadline is extended until 31 December 2023 (Art. 11 (6) ATAD).

71 For a more recent overview of the availability of interest deduction limitation rules across Member States, see Bräutigam et al. (2019), pp. 541-543. 
Table 2: EATR of a debt-financed resident corporation before and after the Lankhorst-Hohorst case (2001)

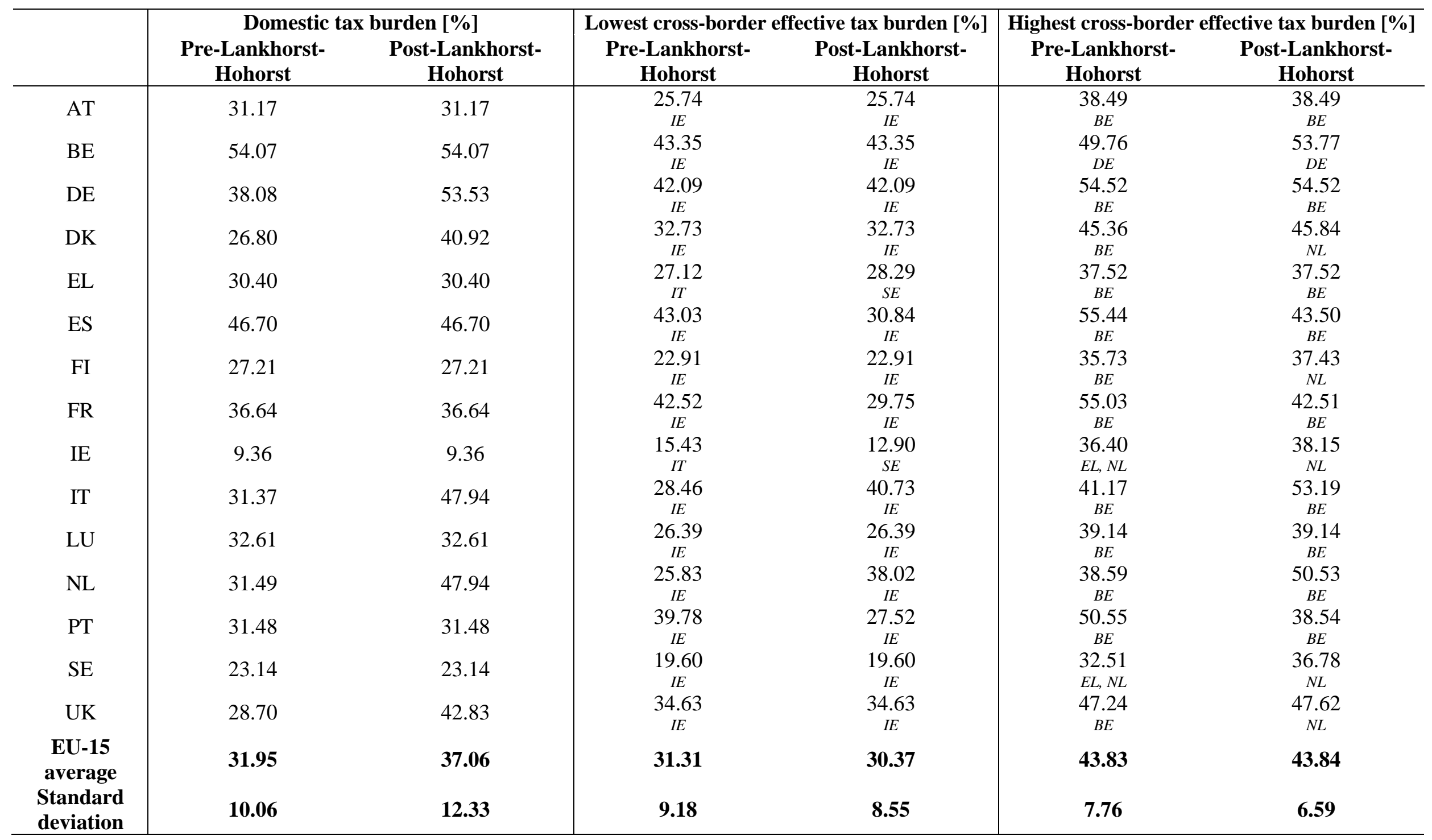




\section{Deductibility of Foreign Final Losses and the "Marks \& Spencer" Case}

\subsection{Case setting and preliminary remarks}

Although the ECJ had already ruled on intra-company relief of cross-border losses before, the "Marks \& Spencer" case (C-446/03) $)^{72}$ is of decisive impact and represents the first case on such relief within a corporate group. ${ }^{73}$ As such, it relates to the compatibility of the United Kingdom rules for group loss relief with EU law: Marks \& Spencer plc was incorporated and registered in the United Kingdom and claimed group tax relief for losses of its foreign subsidiaries that had either ceased trading (Belgian and German subsidiaries) or had been sold to a third party (French subsidiary). ${ }^{74}$ The tax authorities in the United Kingdom denied such relief, however, and claimed that the possibility to surrender losses of another group company was restricted to domestic losses. ${ }^{75}$ In the related preliminary ruling of 13 December 2005, the ECJ held that this restriction infringed the freedom of establishment (Art. 43 EC/Art. 49 TFEU) if the foreign subsidiary (or any third party upon a sale of the subsidiary) had exhausted all possibilities to take account of the losses in prior, current or future periods. ${ }^{76}$

To analyse the impact of the Marks \& Spencer case on effective tax rates and hence, its contribution to a better functioning of the internal market, we consider a parent company that splits its investment into a domestic investment in its residence state and a cross-border investment through its foreign subsidiary. The subsidiary's investment yields a pre-specified negative return whereas the pre-tax return of the parent's domestic investment is positive. Furthermore, we assume that the subsidiary's loss is final, i.e. the subsidiary has exhausted all possibilities for taking the losses into account. In case intra-group loss compensation is available, the subsidiary's loss is attributed to the parent entity and reduces its taxable income accordingly. If no such consolidation mechanism is available, the parent entity must cover the final loss of its affiliate without any comparable tax relief.

As a benchmark for the cross-border case, we analyse Member States' respective tax treatment of loss-making domestic affiliates including the potential availability of a consolidation of intragroup domestic losses. All calculations are based on 2004 tax data.

72 ECJ, 13 December 2005, Case C-446/03, Marks \& Spencer plc v. David Halsey (Her Majesty's Inspector of Taxes).

73 See de la Feria/Fuest (2011), p. 35.

74 See Marks \& Spencer (C-446/03), para. 18-26 for the case setting and prior legal procedure.

75 See Marks \& Spencer (C-446/03), para. 24

76 See Marks \& Spencer (C-446/03), para. 59. For a legal discussion of the Marks \& Spencer case, see, for instance, Lang (2006). 
In Appendix A.2.2., we provide a detailed description of the amendments to the basic formulas of the Devereux/Griffith model.

\subsection{Member States' tax law adjustments in the context of the case}

In Table 3, we summarise the availability and scope of intra-group loss compensation across Member States before and after the ruling in the Marks \& Spencer case. ${ }^{77}$ Although intra-group loss compensation was available in 18 out of 24 Member States before the judgement, the mechanism was restricted to losses of domestic subsidiaries in the vast majority of Member States. It was only possible to surrender losses of foreign subsidiaries in Denmark, France and Italy. The European Commission has also emphasised that a lack or limited availability of crossborder intra-group loss relief would not only favour large companies or companies situated in large Member States, but would also impede the realisation of the internal market by disadvantaging cross-border investments. As such, the European Commission has stressed the need to provide for an effective cross-border intra-firm and intra-group loss offset. ${ }^{78}$

Member States' tax law adjustments following the Marks \& Spencer ruling were rather heterogeneous: Whereas five Member States extended the scope of cross-border intra-group loss relief to other Member States (or even third countries), only Slovenia denied the possibility of domestic group relief and thus abolished intra-group loss consolidation altogether. The overwhelming majority of nine Member States that granted unequal treatment to the group-wide surrender of domestic and EU-wide cross-border losses, however, maintained the former (discriminatory) scope of their rules. As such, there are no common general characteristics of these Member States since they include both "old" and "new" Member States (e.g. Finland, Poland), large and small countries (e.g. Germany, the Netherlands) as well as high-tax and low-tax countries (e.g. Spain, Cyprus). No Member State newly introduced any form of intra-group surrender of losses following the Marks \& Spencer case.

Legal uncertainties regarding the scope of cross-border intra-group loss offset have been suggested as a potential explanation for Member States' maintenance of (discriminatory) regulations after the judgement. ${ }^{79}$ Open questions included, for instance, the determination of the finality of a loss, the relevant timing for cross-border loss compensation as well as repercussions

\footnotetext{
77 The presentation of country practice follows the presentation by de la Feria/Fuest (2011), p. 39; de la Feria/Fuest (2016), pp. $66 \mathrm{f}$.

78 See European Commission (2006), pp. 3, 10; de la Feria/Fuest (2011), p. 39.

79 See de la Feria/Fuest (2011), p. 40.
} 
on the design of domestic loss compensation rules and the associated distribution of tax revenues ${ }^{80}$ Furthermore, it was neither clear whether the scope of the judgement was restricted only to group relief systems that mirrored the United Kingdom's model nor whether the principles of the ruling should also extend to intra-firm compensation of losses of a foreign permanent establishment. ${ }^{81}$ In fact, the ECJ departed from the principles established in Marks \& Spencer in several partly contradicting subsequent rulings such as - among others - Lidl Belgium (C414/06), ${ }^{82}$ Oy AA (C-231/05), ${ }^{83}$ Krankenheim Ruhesitz am Wannsee (C-157/07) ${ }^{84}$ or K (C$322 / 11)^{85} \cdot{ }^{86}$

Table 3: Member States' adjustments following the Marks \& Spencer case

\begin{tabular}{|c|c|c|c|c|}
\hline & \multicolumn{4}{|c|}{ Scope of intra-group loss consolidation } \\
\hline & \multicolumn{2}{|c|}{ Pre-Marks \& Spencer } & \multicolumn{2}{|c|}{ Post-Marks \& Spencer } \\
\hline & National & EU Member States & National & EU Member States \\
\hline AT & $\mathrm{x}$ & - & $\mathrm{x}$ & $\mathbf{x}$ \\
\hline $\mathrm{BE}$ & - & - & - & - \\
\hline $\mathrm{CY}$ & $\mathrm{x}$ & - & $\mathrm{x}$ & - \\
\hline $\mathrm{CZ}$ & - & - & - & - \\
\hline $\mathrm{DE}$ & $\mathrm{x}$ & - & $\mathrm{x}$ & - \\
\hline DK & $\mathrm{x}$ & $\mathrm{x}$ & $\mathrm{x}$ & $\mathrm{x}$ \\
\hline EL & - & - & - & - \\
\hline ES & $\mathrm{x}$ & - & $\mathrm{x}$ & - \\
\hline FI & $\mathrm{x}$ & - & $\mathrm{x}$ & - \\
\hline FR & $\mathrm{x}$ & $\mathrm{x}$ & $\mathrm{x}$ & $\mathrm{x}$ \\
\hline HU & - & - & - & - \\
\hline IE & $\mathrm{x}$ & - & $\mathrm{x}$ & $\mathbf{x}$ \\
\hline IT & $\mathrm{x}$ & $\mathrm{x}$ & $\mathrm{x}$ & $\mathrm{x}$ \\
\hline $\mathrm{LT}$ & - & - & - & - \\
\hline LU & $\mathrm{x}$ & - & $\mathrm{x}$ & - \\
\hline LV & $\mathrm{x}$ & - & $\mathrm{x}$ & $\mathbf{x}$ \\
\hline MT & $\mathrm{x}$ & - & $\mathrm{x}$ & - \\
\hline NL & $\mathrm{x}$ & - & $\mathrm{x}$ & - \\
\hline PL & $\mathrm{x}$ & - & $\mathrm{x}$ & - \\
\hline PT & $\mathrm{x}$ & - & $\mathrm{x}$ & - \\
\hline SE & $\mathrm{x}$ & - & $\mathrm{x}$ & $\mathbf{x}$ \\
\hline SI & $\mathrm{x}$ & - & - & - \\
\hline SK & - & - & - & - \\
\hline UK & $\mathrm{x}$ & - & $\mathrm{x}$ & $\mathbf{x}$ \\
\hline
\end{tabular}

$x=$ intra-group loss consolidation available

- = intra-group loss consolidation not available

The highlighted characteristics represent changes to the domestic rules that occur in the context of the Marks \& Spencer case.

See Lang (2006), pp. 61-63; Lang (2014), pp. 530 f. with further references.

See Panayi (2010), p. 279.

82 ECJ, 15 May 2008, Case C-414/06, Lidl Belgium GmbH \& Co. KG v Finanzamt Heilbronn.

83 ECJ, 18 July 2007, Case C-231/05, Oy AA.

84 ECJ, 23 October 2008, Case C-157/07, Finanzamt für Körperschaften III in Berlin v Krankenheim Ruhesitz. am Wannsee-Seniorenheimstatt GmbH.

85 ECJ, 7 November 2013, Case C-322/11, K.

86 See Lang (2014) as well as Panayi (2010), pp. 281-288 for a detailed overview and description of subsequent case law. 


\subsection{Implications of the "Marks \& Spencer" case for the realisation of the internal market}

In Table 4, we illustrate the EATR in the loss scenario before and after the Marks \& Spencer ruling. As such, the domestic case indicates the tax burden that would result if a parent entity has a loss-making domestic subsidiary whereas in the cross-border case it is assumed that a loss of similar amount is generated by a foreign subsidiary. The tax treatment of domestic or foreign group losses depends on the rules of the Member State where the parent is resident (Table 3).

Before the Marks \& Spencer judgement, the (unweighted) average EATR for a parent with a domestic loss-making subsidiary is equal to $21.04 \%$ whereas the (unweighted) average EATR for the case of foreign losses amounts to $21.90 \%$. Group-wide surrender of losses was restricted to domestic losses in 15 Member States resulting in a different EATR for the domestic and cross-border cases. These differences vary between 0.62 percentage points in Ireland and 2.02 percentage points in Spain with an average difference of 0.86 percentage points. Although the final loss must still be borne by the parent, it does not have any tax burden reducing effect if no group-wide loss relief is available. Hence, the tax burden in the cross-border loss case is higher if the scope of group-wide loss relief is restricted to domestic losses. The difference is 0 in case Member States either do not grant group-wide surrender of losses at all or if such relief is also available for losses of foreign subsidiaries (Denmark, France, Italy).

After the judgement, the (unweighted) average EATR for a parent with a domestic loss-making subsidiary slightly increases to $21.09 \%$ due to the overall abolition of group loss consolidation in Slovenia. For a parent with foreign losses, however, the (unweighted) average EATR slightly decreases to $21.65 \%$ as a result of the extension of group loss consolidation in five Member States. As evident from the zero difference between domestic and cross-border EATR, the treatment of domestic and foreign losses is aligned in these countries.

The (unweighted) average difference in tax burdens between the domestic and cross-border loss cases still amounts to 0.56 percentage points. Yet, as nine Member States continue to apply a different treatment for domestic and cross-border losses, there is no full alignment of the related EATR either. 
Table 4: EATR in loss scenario before and after the Marks \& Spencer case (2004)

\begin{tabular}{|c|c|c|c|c|c|c|}
\hline EATR & \multicolumn{3}{|c|}{ Pre-Marks \& Spencer } & \multicolumn{3}{|c|}{ Post-Marks \& Spencer } \\
\hline AT & 28.02 & 29.72 & 1.70 & 28.02 & 28.02 & 0.00 \\
\hline $\mathrm{CY}$ & 9.07 & 9.82 & 0.75 & 9.07 & 9.82 & 0.75 \\
\hline $\mathrm{CZ}$ & 22.01 & 22.01 & 0.00 & 22.01 & 22.01 & 0.00 \\
\hline DE & 32.34 & 34.31 & 1.97 & 32.34 & 34.31 & 1.97 \\
\hline $\mathrm{ES}$ & 33.21 & 35.23 & 2.02 & 33.21 & 35.23 & 2.02 \\
\hline FI & 21.72 & 23.17 & 1.45 & 21.72 & 23.17 & 1.45 \\
\hline FR & 27.29 & 27.29 & 0.00 & 27.29 & 27.29 & 0.00 \\
\hline HU & 13.73 & 13.73 & 0.00 & 13.73 & 13.73 & 0.00 \\
\hline $\mathrm{IE}$ & 6.88 & 7.50 & 0.62 & 6.88 & 6.88 & 0.00 \\
\hline IT & 29.54 & 29.54 & 0.00 & 29.54 & 29.54 & 0.00 \\
\hline $\mathrm{LT}$ & 9.21 & 9.21 & 0.00 & 9.21 & 9.21 & 0.00 \\
\hline PT & 21.11 & 22.49 & 1.38 & 21.11 & 22.49 & 1.38 \\
\hline SE & 18.20 & 19.48 & 1.28 & 18.20 & 18.20 & 0.00 \\
\hline SI & 18.21 & 19.46 & 1.25 & 19.46 & 19.46 & 0.00 \\
\hline SK & 13.17 & 13.17 & 0.00 & 13.17 & 13.17 & 0.00 \\
\hline UK & 22.71 & 24.21 & 1.50 & 22.71 & 22.71 & 0.00 \\
\hline EU-24 average & 21.04 & 21.90 & 0.86 & 21.09 & 21.65 & 0.56 \\
\hline $\begin{array}{l}\text { Standard } \\
\text { deviation }\end{array}$ & 8.02 & 8.30 & 0.76 & 8.00 & 8.34 & 0.78 \\
\hline
\end{tabular}


On average, hence, although the Marks \& Spencer case and Member States' adjustments to their rules on intra-group loss compensation contribute to aligning domestic and cross-border investments from the perspective of single Member States, no full equality is reached and some obstacles to cross-border business activity remain. Besides, whereas the standard deviation of domestic EATR slightly decreases following the adjustments to the Marks \& Spencer judgement (from 8.02 to 8.00), it slightly increases for the cross-border case (from 8.30 to 8.34) which indicates that the spread in cross-border tax burdens upon subsidiary losses increases among Member States. As such, the contribution of the Marks \& Spencer case and Member States' related tax law adjustments towards the establishment of an internal market seems - if at all - rather modest.

\section{Controlled Foreign Company Rules and the "Cadbury Schweppes" Case}

\subsection{Case setting and preliminary remarks}

The "Cadbury Schweppes“" case (C-196/04) $)^{87}$ challenged the conformity of the United Kingdom's CFC rules against the background of EU law. Despite the general tax exemption of a foreign subsidiary's profits in the United Kingdom, the profits of a CFC (participation > 50\%) might be taxed in the United Kingdom provided that the CFC is subject to low taxation in the sense that its tax liability does not exceed a threshold of three quarters of the liability that would have resulted under the rules applicable in the United Kingdom. ${ }^{88}$ In the case at hand, United Kingdom resident parent company Cadbury Schweppes plc had, among others, two Irish subsidiaries held as financing companies that were subject to a tax rate of $10 \%$ which triggered the application of CFC rules. ${ }^{89}$ The ECJ held such a rule incompatible with the freedom of establishment (Art. 43 EC/Art. 49 TFEU) in its judgement of 12 September 2006 and required its scope to be restricted to wholly artificial arrangements without economic substance. ${ }^{90}$ As CFC rules seem to play an important role in corporate investment decisions, ${ }^{91}$ a restriction of such rules to third country relationships might enhance intra-EU tax competition. ${ }^{92}$

To analyse the impact of the Cadbury Schweppes case on investment conditions among Member States, we follow the general approach of Bräutigam et al. (2017) and assume that a parent

87 ECJ, 12 September 2006, Case C-196/04, Cadbury Schweppes plc, Cadbury Schweppes Overseas Ltd v Commissioners of Inland Revenue.

88 See Cadbury Schweppes (C-196/04), para. 3-12 for a detailed overview on the underlying legislation.

89 See Cadbury Schweppes (C-196/04), para. 13-28 for the case setting and prior legal procedure.

90 See Cadbury Schweppes (C-196/04), para. 75. For a detailed description and discussion of the case, see, for instance Meussen (2007).

91 See, for instance, references to Ruf/Weichenrieder (2012) and Ruf/Weichenrieder (2013) in Bräutigam et al. (2017), pp. $721 \mathrm{f}$.

92 See Bräutigam et al. (2017), p. 722. 
corporation situated in one Member State invests into a subsidiary located in any other Member State. In terms of a comprehensive analysis, we assume a weighted investment across all five kinds of assets instead of the mere acquisition of a patent. Furthermore, we assume that all other prerequisites for the applicability of CFC rules are fulfilled and hence only the low taxation criterion is decisive.

The outbound investment under consideration bears a tax burden of EATR $R_{\text {cross-border }}$ CFC rules apply if this tax burden falls short of a threshold specified by the CFC rules of the parent's residence country. In this case, the cross-border investment is taxed as if it was a domestic investment in the residence state of the parent company. Hence, the EATR for a cross-border investment under the application of CFC rules equals at least the EATR for a domestic investment in the parent company's residence state. In contrast, if the outbound investment's tax burden exceeds the CFC threshold established by the parent's residence country, the outbound

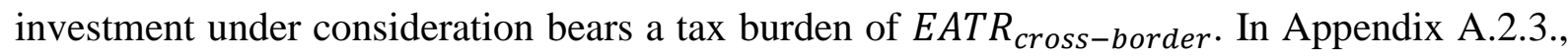
we provide a detailed description of the amendments to the basic formulas of the Devereux/Griffith model.

We benchmark the outcomes of the cross-border investment (including CFC rules) against the case of a domestic investment in the residence state of the parent. All calculations are based on 2005 tax data.

\subsection{Member States' tax law adjustments in the context of the case}

In Table 5, we illustrate the general availability and scope of CFC rules before and after the Cadbury Schweppes case across Member States.

Although the tax laws of eleven Member States included a CFC rule, it did not apply in relation to EU or EEA Member States already prior to the judgement in five countries. ${ }^{93}$ In the context of the ECJ's ruling in the Cadbury Schweppes case, five countries amended their CFC rules by an EU/EEA clause to limit the applicability of CFC rules to third countries. The scope of the exemption went even further in Hungary by likewise including third countries that have concluded a tax treaty with Hungary. By contrast, Denmark is the only Member State that extended the scope of its CFC rules and implemented a modified CFC regime that covers both Danish and foreign entities. Under the new system, among others, CFC rules apply if more than half of

93 Under the Spanish and Swedish rules, certain types of income arising in Member States such as Luxembourg, Belgium or Cyprus constituted taxable CFC income. However, as this covers very specific types of income, we assume a general non-applicability of CFC rules in relation to those Member States, respectively. 
the income of a subsidiary constitutes CFC income including capital income (interest, dividends, and capital gains) rather than upon a general low level of taxation. ${ }^{94}$ As such, Member States' adjusted CFC rules comply with the enhanced intra-EU requirements for CFC rules following the Cadbury Schweppes ruling.

Table 5: Member States' adjustments following the Cadbury Schweppes case

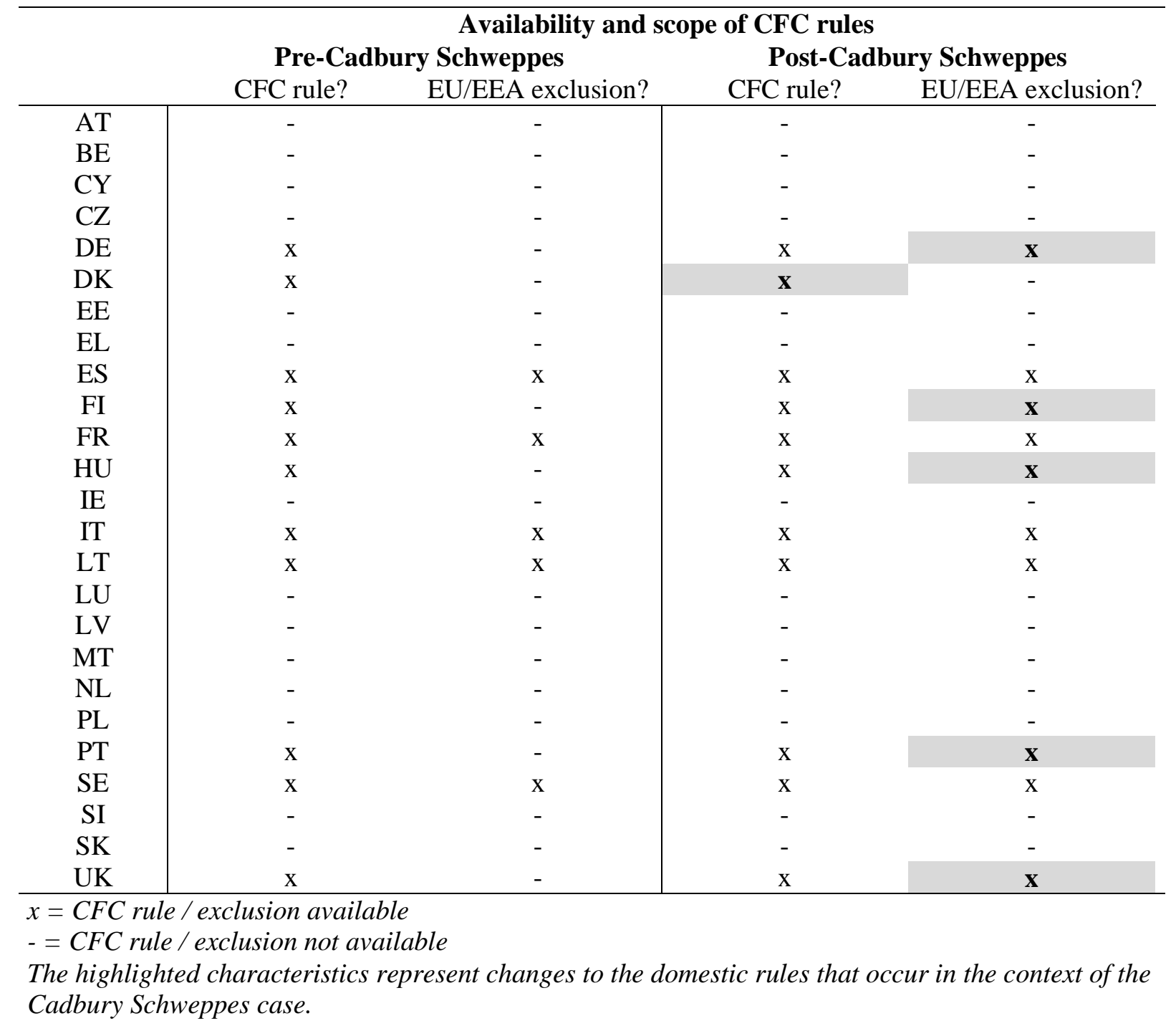

\subsection{Implications of the "Cadbury Schweppes" case for the realisation of the internal market}

As a benchmark, the first column in Table 6 illustrates the EATR for domestic investments. The unweighted average EATR for the EU-25 Member States amounts to 27.36\% whereas the standard deviation of 8.23 indicates a considerable spread in domestic EATR that vary between

94 See Koerver Schmidt (2013), pp. 266-274 for a detailed description of the amended Danish CFC legislation. For an analysis of the new Danish CFC rules in light of EU law, see Koerver Schmidt (2013), pp. $276 \mathrm{f}$. and Koerver Schmidt (2014). 
$11.93 \%$ in Cyprus and 40.77\% in Spain. For cross-border investments (columns 2 to 4), we illustrate the lowest and highest EATR before and after the Cadbury Schweppes judgement including the potential applicability of CFC rules. ${ }^{95}$

In general, the lowest possible cross-border EATR are lower than domestic EATR in all Member States except Cyprus, Greece and Ireland even upon the potential application of CFC rules before the Cadbury Schweppes judgement (unweighted averages of 16.67\% v 27.36\%). This indicates a general preference for cross-border investment. Although it is lower than in the domestic case, there is a considerable spread in cross-border EATR across Member States which is illustrated by the standard deviation of 7.42 ; the lowest possible cross-border EATR vary between 11.93\% (Austria, Czech Republic, Estonia, Hungary, Latvia, Lithuania, Luxembourg, Netherlands, Poland, Spain, Sweden, Slovenia, Slovak Republic) and 32.08\% (Greece).

Potential changes to cross-border EATR will only result for Member States that apply CFC rules which were amended by an EU/EEA clause following the Cadbury Schweppes judgement (Denmark, Germany, Hungary, Portugal, and United Kingdom). From the perspective of a Finnish, German or Portuguese parent corporation, the amended CFC rules have widened investment choices and have further enhanced the attractiveness of cross-border investment. The decline in the lowest possible EATR is most pronounced in Germany (almost 13 percentage points) whereas it is of similar magnitude in Finland and Portugal (roughly 4 percentage points). The highest possible EATR do not change upon a potential non-applicability of CFC rules following the Cadbury Schweppes case. The strong decline in Germany traces back to the interplay between a comparatively high domestic tax level and a strict threshold for low taxation at $25 \%$ established in the CFC rules. As such, CFC rules apply in relation to CFCs resident in seven Member States (Cyprus, Hungary, Ireland, Latvia, Lithuania, Poland, and Slovak Republic) before the amendment by an EU/EEA clause. For an outbound investment into a Cypriot subsidiary, for instance, the associated gross-up to German domestic tax levels following the applicability of CFC rules would increase the EATR for cross-border investment by roughly 26 percentage points (from $13.85 \%$ to $39.83 \%$ ). Hence, upon the non-applicability of CFC rules in relation to low-taxed EU subsidiaries, the average EATR for outbound investments of a German parent entity decreases quite considerably. The lowest possible EATR for cross-border

95 Other than Bräutigam et al. (2017) who depict unweighted average inbound and outbound EATR across all possible investment locations, we consider the lowest and highest possible outbound EATR for the respective residence country of the parent entity. As only a limited number of Member States applies CFC rules to intraEU investment prior to the Cadbury Schweppes case and most Member States exempt foreign dividend income, if any, we would observe only very small average effects following the limited applicability of CFC rules among Member States. At the same time, the causes of the changes would remain largely unknown. 
investment can now be achieved upon an investment into a Cypriot subsidiary whereas the lowest possible EATR has resulted upon an investment into a subsidiary resident in Slovenia (at $26.77 \%$ ) before the necessary amendments following the Cadbury Schweppes case were adopted.

In Hungary, the threshold for low taxation of a foreign affiliate is at two thirds of the regular Hungarian corporate income tax rate of $16 \%$ (i.e. 10.67\%). For such low threshold, CFC rules do not apply in relation to any other country in the case at hand. Hence, the amendment of Hungary's CFC rules to exclude foreign entities resident in the EU, OECD or a country with which Hungary has concluded a tax treaty does not have any effect in our model calculations.

Although the scope and applicability of CFC rules is limited in the United Kingdom following the Cadbury Schweppes judgement, the judgement does not seem to affect cross-border corporate investment choices and the lowest possible EATR remains available upon an investment into Luxembourg. This stems from the application of a credit system under which profit distributions from foreign affiliates are subject to tax in the United Kingdom whereas credit relief is available for foreign taxes paid. As such, the credit system realises CEN and the EATR is largely determined by the domestic tax level.

In contrast, the lowest possible EATR for Danish cross-border investment increases by 3.40 percentage points upon the amendments following the Cadbury Schweppes judgement: As illustrated in Section 6.2., Denmark has subsequently adopted an extended CFC regime that applies group taxation rules to both domestic and foreign entities. By assumption, this would establish a minimum EATR level of $28.50 \%$ and hence lead to an overall increase in the average outbound EATR for Danish parent corporations. In line with the increase in the lowest possible EATR level, CEN is established in relation to the majority of Member States.

As such, EATR levels in Finland, Germany and Portugal are adjusted to Member States where no CFC legislation applies and low cross-border tax levels could be achieved irrespective of the Cadbury Schweppes case. Under 100\% equity financing, the EATR for cross-border investment corresponds to the EATR for domestic investment in the residence country of the subsidiary if the residence country of the parent applies the exemption method for foreign dividends (CIN). Nevertheless, differences in cross-border tax burdens persist for Member States such as France, Germany or Italy where the exemption is limited to $95 \%$ of the received dividends. 
Besides, (cross-border) investment into Cyprus ${ }^{96}$ is not the universal preferred investment option across all Member States: For corporations situated in Malta and the United Kingdom, investing into a subsidiary located in Belgium (Maltese parent) or Luxembourg (United Kingdom parent) yields the lowest tax burden whereas Greek and Irish parent entities would prefer domestic investment due to the application of a credit system. As evident from the case of a parent entity situated in the United Kingdom, these preferences persist irrespective of the application of CFC rules. For a parent corporation situated in Denmark, both domestic as well as cross-border investment into 14 other countries would yield the same (lowest) EATR. Overall, the spread in lowest cross-border EATR measured by the standard deviation slightly increases (from 7.42 to 7.44) following Member States adjustments to the Cadbury Schweppes case.

Overall, although the ECJ's decision in the Cadbury Schweppes case has contributed to promoting cross-border business activities among Member States and to the establishment of a European internal market from the perspective of single Member States, its impact seems to be of limited scope: On the one hand, CFC rules were applicable in relation to related entities resident in other Member States only in a small number of countries before the ECJ rendered its decision in the Cadbury Schweppes case. On the other hand, differences in cross-border EATR persist due to the application of different methods for avoidance of double taxation of dividends (credit v exemption) as well as due to different levels of dividend exemption even if $\mathrm{CFC}$ rules cease to be applicable in relation to EU affiliates. Besides, from the perspective of Danish corporations, cross-border investment choices are limited upon the wider scope of CFC rules following the Cadbury Schweppes case.

Upon the mandatory application of the ATAD as of 1 January 2019, all Member States have been obliged to implement CFC rules in line with the minimum standards established by Articles 7/8 ATAD. This has induced a need for adjustment in roughly half of the Member States. ${ }^{97}$ In line with the Cadbury Schweppes doctrine, Article 7 (2) a) ATAD nevertheless limits the applicability of CFC rules to wholly artificial arrangements within the EU. ${ }^{98}$ As such, the implementation of the CFC rules established by the ATAD will presumably not affect corporate investment choices.

\footnotetext{
96 As evident from Table 6, a Cypriot parent entity would prefer domestic to cross-border investment.

97 See Gutmann et al. (2017), pp. 12-16 for an analysis of Member States CFC rules against the standard established by Articles 7/8 ATAD.

98 See also Schönfeld (2017), p. 146; Dehne (2018), pp. 134 f.
} 
Table 6: Cross-border EATR before and after the Cadbury Schweppes case (2006)

\begin{tabular}{|c|c|c|c|c|}
\hline & \multirow{2}{*}{$\begin{array}{c}\text { Domestic } \\
\text { tax burden [\%] }\end{array}$} & \multicolumn{2}{|c|}{$\begin{array}{l}\text { Lowest cross-border } \\
\text { effective tax burden [\%] }\end{array}$} & \multirow{2}{*}{$\begin{array}{l}\text { Highest cross- } \\
\text { border effective } \\
\text { tax burden [\%] }\end{array}$} \\
\hline & & $\begin{array}{c}\text { Pre-Cadbury } \\
\text { Schweppes } \\
\end{array}$ & $\begin{array}{c}\text { Post-Cadbury } \\
\text { Schweppes }\end{array}$ & \\
\hline AT & 26.03 & $\begin{array}{c}11.93 \\
C Y\end{array}$ & $\begin{array}{c}11.93 \\
C Y\end{array}$ & $\begin{array}{c}40.77 \\
E S\end{array}$ \\
\hline $\mathrm{BE}$ & 33.67 & $\begin{array}{c}13.59 \\
C Y\end{array}$ & $\begin{array}{c}13.59 \\
C Y\end{array}$ & $\begin{array}{c}41.94 \\
E S\end{array}$ \\
\hline $\mathrm{CY}$ & 11.93 & $\begin{array}{c}14.56 \\
L T\end{array}$ & $\begin{array}{c}14.56 \\
L T\end{array}$ & $\begin{array}{c}40.77 \\
E S\end{array}$ \\
\hline $\mathrm{CZ}$ & 25.91 & $\begin{array}{c}11.93 \\
C Y\end{array}$ & $\begin{array}{c}11.93 \\
C Y\end{array}$ & $\begin{array}{c}40.77 \\
E S\end{array}$ \\
\hline DE & 39.83 & $\begin{array}{c}26.77 \\
S I\end{array}$ & $\begin{array}{c}13.85 \\
C Y\end{array}$ & $\begin{array}{c}42.13 \\
E S\end{array}$ \\
\hline DK & 28.50 & $\begin{array}{c}25.10 \\
S I\end{array}$ & $\begin{array}{c}28.50 \\
\text { All countries ex. } B E, D E, E L, \text {, } \\
E S, F R, I T, L U, M T, N L, U K\end{array}$ & $\begin{array}{c}40.77 \\
E S\end{array}$ \\
\hline $\mathrm{EE}$ & 26.35 & $\begin{array}{c}11.93 \\
C Y\end{array}$ & $\begin{array}{c}11.93 \\
C Y\end{array}$ & $\begin{array}{c}40.77 \\
E S\end{array}$ \\
\hline EL & 31.70 & $\begin{array}{c}32.08 \\
L U\end{array}$ & $\begin{array}{c}32.08 \\
L U\end{array}$ & $\begin{array}{c}40.77 \\
E S\end{array}$ \\
\hline ES & 40.77 & $\begin{array}{c}11.93 \\
C Y\end{array}$ & $\begin{array}{c}11.93 \\
C Y\end{array}$ & $\begin{array}{c}39.83 \\
D E\end{array}$ \\
\hline FI & 27.65 & $\begin{array}{c}16.10 \\
L V\end{array}$ & $\begin{array}{c}11.93 \\
C Y\end{array}$ & $\begin{array}{c}40.77 \\
E S\end{array}$ \\
\hline FR & 39.07 & $\begin{array}{c}13.63 \\
C Y\end{array}$ & $\begin{array}{c}13.63 \\
C Y\end{array}$ & $\begin{array}{c}41.97 \\
E S\end{array}$ \\
\hline $\mathrm{HU}$ & 18.58 & $\begin{array}{c}11.93 \\
C Y\end{array}$ & $\begin{array}{c}11.93 \\
C Y\end{array}$ & $\begin{array}{c}40.77 \\
E S\end{array}$ \\
\hline IE & 16.17 & $\begin{array}{c}25.10 \\
\text { SI }\end{array}$ & $\begin{array}{c}25.10 \\
S I\end{array}$ & $\begin{array}{c}40.77 \\
E S\end{array}$ \\
\hline IT & 35.80 & $\begin{array}{c}13.54 \\
C Y\end{array}$ & $\begin{array}{c}13.54 \\
C Y\end{array}$ & $\begin{array}{c}41.01 \\
E S\end{array}$ \\
\hline LT & 14.56 & $\begin{array}{c}11.93 \\
C Y\end{array}$ & $\begin{array}{c}11.93 \\
C Y\end{array}$ & $\begin{array}{c}40.77 \\
E S\end{array}$ \\
\hline $\mathrm{LU}$ & 30.22 & $\begin{array}{c}11.93 \\
C Y\end{array}$ & $\begin{array}{c}11.93 \\
C Y\end{array}$ & $\begin{array}{c}40.77 \\
E S\end{array}$ \\
\hline LV & 16.10 & $\begin{array}{c}11.93 \\
C Y\end{array}$ & $\begin{array}{c}11.93 \\
C Y\end{array}$ & $\begin{array}{c}40.77 \\
E S\end{array}$ \\
\hline MT & 36.51 & $\begin{array}{c}34.83 \\
B E\end{array}$ & $\begin{array}{c}34.83 \\
B E\end{array}$ & $\begin{array}{c}40.77 \\
E S\end{array}$ \\
\hline NL & 32.22 & $\begin{array}{c}11.93 \\
C Y\end{array}$ & $\begin{array}{c}11.93 \\
C Y\end{array}$ & $\begin{array}{c}40.77 \\
E S\end{array}$ \\
\hline PL & 19.40 & $\begin{array}{c}11.93 \\
C Y\end{array}$ & $\begin{array}{c}11.93 \\
C Y\end{array}$ & $\begin{array}{c}40.77 \\
E S\end{array}$ \\
\hline PT & 27.91 & $\begin{array}{c}16.10 \\
L V\end{array}$ & $\begin{array}{c}11.93 \\
C Y\end{array}$ & $\begin{array}{c}40.77 \\
E S\end{array}$ \\
\hline SE & 27.96 & $\begin{array}{c}11.93 \\
C Y\end{array}$ & $\begin{array}{c}11.93 \\
C Y\end{array}$ & $\begin{array}{c}40.77 \\
E S\end{array}$ \\
\hline SI & 25.10 & $\begin{array}{c}11.93 \\
C Y\end{array}$ & $\begin{array}{c}11.93 \\
C Y\end{array}$ & $\begin{array}{c}40.77 \\
E S\end{array}$ \\
\hline SK & 19.13 & $\begin{array}{c}11.93 \\
C Y\end{array}$ & $\begin{array}{c}11.93 \\
C Y\end{array}$ & $\begin{array}{c}40.77 \\
E S\end{array}$ \\
\hline UK & 32.99 & $\begin{array}{c}30.22 \\
L U\end{array}$ & $\begin{array}{c}30.22 \\
L U\end{array}$ & $\begin{array}{c}40.77 \\
E S\end{array}$ \\
\hline EU-25 average & 27.36 & 16.67 & 15.95 & 40.89 \\
\hline $\begin{array}{l}\text { Standard } \\
\text { deviation }\end{array}$ & 8.23 & 7.42 & 7.44 & 0.47 \\
\hline
\end{tabular}




\section{Exit Taxation and the "National Grid Indus" Case}

\subsection{Case setting and preliminary remarks}

In the "National Grid Indus" case (C-371/10) $)^{99}$ on corporate exit taxation rules, Dutch limited liability corporation National Grid Indus BV had a claim against National Grid Company plc established in the United Kingdom which carried an unrealised exchange rate gain. ${ }^{100}$ By virtue of the double taxation convention between the Netherlands and the United Kingdom, National Grid Indus BV was no longer liable to tax in the Netherlands upon the transfer of its place of effective management to the United Kingdom. As such, the Dutch tax authorities wanted to tax the unrealised exchange rate gain. In its ruling of 29 November 2011, the ECJ held that exit tax was in principle chargeable on an unrealised capital gain upon the transfer of a company's place of effective management to another Member State. It further held, however, that the immediate recovery of such unrealised capital gain would infringe the freedom of establishment (Article 49 TFEU). ${ }^{101}$ The judgement in the National Grid Indus case constitutes a landmark decision as it is the first precedent in the second phase of case law on exit taxes: ${ }^{102}$ During the first phase, the ECJ dealt with exit taxes imposed upon the expatriation of individuals to another Member State (e.g. the "Lasteyrie du Saillant" and "N" cases) $)^{103}$ and found that exit taxes might represent an unjustified restriction to the freedom of establishment. During the second phase of case law where the scope was extended to corporations, the ECJ held that such restriction might be justified and proportionate upon a staggered recovery of the resulting exit tax liability. In this context, Schön (2015) also notes a change in the ECJ's perception of the internal market: Whereas prior jurisprudence had rather emphasised the concept of a single market without any internal borders, the ECJ seemed to recognise the legitimacy of such borders upon the decision in the National Grid Indus case. ${ }^{104}$

If an entity transfers its legal seat or place of effective management abroad, exit taxes usually apply on the unrealised capital gains that have accrued in its assets (defined as fair value - tax book value of assets). To illustrate the effects of such a transfer within the framework of the Devereux/Griffith model, we assume that the transferring firm only owns a self-created patent

99 ECJ, 29 November 2011, Case C-371/10, National Grid Indus BV v Inspecteur van de Belastingdienst Rijnmond / kantoor Rotterdam.

100 See National Grid Indus (C-371/10), para. 10-21 for the case setting and prior legal procedure. The underlying legal context is described in para. 3-9.

101 See National Grid Indus (C-371/10), para. 86.

102 See Koury (2018), pp. $507 \mathrm{f}$. for the following reasoning on the two phases in case law on exit taxation.

103 ECJ, 11 March 2004, Case C-9/02, Hughes de Lasteyrie du Saillant and Ministère de l'Économie, des Finances et de l'Industrie and ECJ, 7 September 2006, Case C-470/04, Nv Insecteur van de Belastingdienst Oost/kantoor Almelo.

104 See Schön (2015), pp. 282 f. 
(equity-financed). Building on the approach of Evers and Spengel (2014), we consider that the patent is subsequently transferred to a foreign subsidiary in order to evaluate the impact of the National Grid Indus case on Member States' exit taxation regimes. The consideration of such transfer and potential associated exit taxes requires several modifications to the baseline formulas of the Devereux/Griffith model as further described in Appendix A.2.4.

In the majority of Member States, self-developed patents cannot be capitalised for tax purposes and hence have a book value of zero. ${ }^{105}$ R\&D costs are expensed immediately and shield part of the return from taxation at the level of the parent entity. ${ }^{106}$ Upon transfer of the patent to a foreign subsidiary, the domestic parent might be subject to exit taxes on the underlying transfer price that - by assumption - corresponds to the earnings value of the patent. ${ }^{107}$ Subsequently, the recipient subsidiary capitalises and depreciates the patent. Furthermore, the return from the exploitation of the patent is subject to tax under the rules of the Member State where the recipient resides.

If the tax code of the transferring parent entity's residence country stipulates to capitalise the patent, exit tax applies on the difference between the transfer price and the book value which corresponds to the costs of creating the patent. To ensure consistency, we additionally account for a "step-up" in the value of the patent to the earnings value (i.e. the transfer price) in case the transferring entity is subject to exit taxes in its residence state. If the Member State where the transferring entity is resident does not impose exit taxes, no step-up is available and the recipient entity capitalises the patent based on its costs.

If a staggered recovery of exit taxes in the residence country of the parent entity over a predefined period is available, we do not account for accrued interest upon deferral. In case national rules allow for deferral until the asset is effectively transferred to a third party such as for instance in Spain, we assume that this deferral is effective within ten years following the transfer.

Based on the (admittedly strong) assumption of a mere tax-motivated transfer of the asset, we exemplify the impact of the National Grid Indus case based on the transfer of a self-developed

\footnotetext{
105 In Cyprus, Portugal and Sweden, however, the capitalisation of self-developed patents is mandatory. In Slovenia, research costs cannot be capitalised whereas domestic law stipulates the capitalisation of development costs. Yet, we assume that there is no capitalisation of the patent in Slovenia and all related costs are immediately expensed for the quantitative analysis in Section 7.3.

106 See Evers/Spengel (2014), p. 6; Evers et al. (2015), pp. 511 f.; Evers (2015), pp. 96 f.

107 See Evers/Spengel (2014), pp. 14-16; Evers (2015), pp. 128 f.
} 
had been rendered. In subsequent years, ten Member States implemented the possibility to defer the payment of exit taxes whereas eight Member States maintained their prior exit tax rules that seemingly discriminated against cross-border transfers. Deferral periods range from five years in Belgium, France or Portugal up to ten years for instance in the Netherlands or United Kingdom. Spain and Luxembourg recover exit taxes upon the termination of the ownership of the asset.

\subsection{Implications of the "National Grid Indus" case for the realisation of the internal market}

In Table 8, we illustrate the EATR for the cross-border transfer of a patent to a low-taxed subsidiary situated in Bulgaria (Cyprus) before and after the ECJ's ruling in the National Grid Indus case, respectively. As a benchmark, the table also includes the EATR for the domestic case where the patent is developed and exploited in the home country of the parent entity.

If the parent entity develops and subsequently uses the patent in its residence country, the (unweighted) average EATR is equal to $18.41 \%$. Among Member States, there is a considerable spread in EATR with the lowest EATR at $7.50 \%$ in Bulgaria and the highest EATR at $30.63 \%$ in Portugal. Apart from the underlying statutory corporate income tax rates, the EATR is driven by the potential capitalisation of R\&D costs and - if the patent must be capitalised - the applicable depreciation methods and rates in the domestic case. Upon capitalisation, there is no immediate tax effect from the creation of the patent in terms of tax-deductible R\&D costs. Rather, the relief is spread over the specified depreciation period.

Upon transfer of the patent to a low-tax subsidiary resident in Bulgaria (Cyprus), the (unweighted) average EATR across Member States amounts to $13.44 \%$ before the ruling in the National Grid Indus case and to 7.62\% after several Member States have adjusted their exit tax regimes by a deferral rule in response to the National Grid Indus case. Already before the ruling, the transfer to a low-tax subsidiary is preferred to the domestic exploitation if the transfer results in a lower EATR. Except for Belgium and Germany, this holds true for Member States that either stipulate the capitalisation of self-developed IP (Cyprus, Portugal, Sweden) and/or do not impose any exit taxes (Austria, Cyprus, Czech Republic, Malta, Romania, Slovenia, Slovak Republic). In contrast to other Member States, a deferral of the exit tax liability was available in Germany prior to the decision in the National Grid Indus case. The advantage from a lower taxation of current returns from the patent in the low-tax country seems to overcompensate the 
disadvantage from the immediate exit tax liability upon transfer in Belgium, Portugal and Sweden. As such, the transfer is preferred despite the immediate application of exit taxes.

Table 8: EATR upon transfer of patent to low-tax subsidiary before and after the National Grid Indus case (2010)

\begin{tabular}{|c|c|c|c|c|c|}
\hline \multirow[b]{2}{*}{ EATR } & \multirow[b]{2}{*}{$\begin{array}{c}\text { Domestic } \\
\text { investment } \\
{[\%]}\end{array}$} & \multicolumn{4}{|c|}{ Transfer to low-tax subsidiary (Bulgaria) } \\
\hline & & $\begin{array}{c}\text { Pre-National } \\
\text { Grid Indus } \\
{[\%]}\end{array}$ & $\begin{array}{c}\text { Post-National } \\
\text { Grid Indus } \\
{[\%]}\end{array}$ & $\begin{array}{c}\text { Change } \\
\text { [percentage } \\
\text { points] }\end{array}$ & $\begin{array}{c}\text { Post-case } \\
\text { difference to } \\
\text { domestic } \\
\text { investment } \\
\text { [percentage } \\
\text { points] } \\
\end{array}$ \\
\hline AT & 18.75 & -15.65 & -15.65 & 0.00 & -34.40 \\
\hline $\mathrm{BE}$ & 25.49 & 25.28 & 15.32 & -9.96 & -10.17 \\
\hline BG & 7.50 & 12.82 & 12.82 & 0.00 & 5.32 \\
\hline CY & 10.56 & 9.79 & 9.79 & 0.00 & -0.78 \\
\hline $\mathrm{CZ}$ & 14.25 & -9.55 & -9.55 & 0.00 & -23.80 \\
\hline DE & 23.21 & 18.11 & 18.11 & 0.00 & -5.10 \\
\hline DK & 18.75 & 22.72 & 13.11 & -9.61 & -5.64 \\
\hline EL & 18.00 & 21.97 & 21.97 & 0.00 & 3.97 \\
\hline ES & 26.80 & 30.77 & 0.06 & -30.72 & -26.75 \\
\hline FI & 19.50 & 23.47 & 23.47 & 0.00 & 3.97 \\
\hline FR & 26.57 & 30.54 & 20.16 & -10.38 & -6.41 \\
\hline $\mathrm{HU}$ & 15.65 & 19.62 & 19.62 & 0.00 & 3.97 \\
\hline $\mathrm{IE}$ & 9.38 & 13.35 & 9.10 & -4.25 & -0.28 \\
\hline IT & 23.48 & 27.45 & 11.57 & -15.87 & -11.90 \\
\hline $\mathrm{LT}$ & 11.25 & 15.22 & 15.22 & 0.00 & 3.97 \\
\hline LU & 21.44 & 25.41 & 0.84 & -24.57 & -20.60 \\
\hline LV & 11.25 & 15.22 & 15.22 & 0.00 & 3.97 \\
\hline MT & 26.25 & -25.83 & -25.83 & 0.00 & -52.08 \\
\hline NL & 19.13 & 23.10 & 10.16 & -12.93 & -8.96 \\
\hline PL & 14.25 & 18.22 & 18.22 & 0.00 & 3.97 \\
\hline PT & 30.63 & 25.72 & 7.11 & -18.61 & -23.51 \\
\hline RO & 12.00 & -6.49 & -6.49 & 0.00 & -18.49 \\
\hline SE & 24.26 & 23.23 & 23.23 & 0.00 & -1.03 \\
\hline SI & 15.00 & -10.56 & -10.56 & 0.00 & -25.56 \\
\hline SK & 14.25 & -9.55 & -9.55 & 0.00 & -23.80 \\
\hline UK & 21.00 & 24.97 & 10.77 & -14.20 & -10.23 \\
\hline $\begin{array}{c}\text { EU-26 } \\
\text { average }\end{array}$ & 18.41 & 13.44 & 7.62 & -5.81 & -10.78 \\
\hline $\begin{array}{l}\text { Standard } \\
\text { deviation }\end{array}$ & 6.25 & 15.91 & 13.23 & 8.84 & 14.62 \\
\hline
\end{tabular}

The negative EATR in Member States without exit taxes (except Cyprus) is striking. It traces back to the immediate tax-effective deductibility of R\&D costs in the residence country of the parent, the tax-free transfer and subsequent exploitation of the patent in a low-tax Member State. By contrast, Cyprus stipulates the capitalisation of the self-developed patent. Although the parent is not liable to exit taxes, the subsequent taxation of the proceeds from the patent in Bulgaria is comparable to the case of domestic taxation which maintains a positive EATR. 
In all ten Member States where the option to defer the exit tax liability was introduced following the National Grid Indus judgement, the transfer of the patent to a subsidiary resident in Bulgaria becomes advantageous compared to the domestic exploitation or the preference is reinforced, respectively. The length of the deferral period is seemingly not decisive. In Luxembourg and Spain, however, the decrease in EATR is especially pronounced following the adjustments to the National Grid Indus judgement. Both countries allow to defer the tax payment until the actual termination of the ownership of the underlying asset. In our calculations, we assume that the Bulgarian subsidiary sells the patent to a third party within ten years after it has received the patent from the Luxembourgian/Spanish parent. Therefore, both the recovery of the exit tax liability after ten years and the taxation of the proceeds from the exploitation of the patent at a considerably lower statutory rate in Bulgaria lead to a very low overall EATR. As a whole, both the average EATR and standard deviation upon transfer decrease because of Member States' adjustments to the National Grid Indus case. In consequence, the transfer of a self-created patent to a low-tax Member State is preferred to domestic exploitation for 19 Member States.

Overall, the National Grid Indus case and the subsequent availability of a deferred recovery of exit taxes in several Member States remarkably enhances the tax favourability of transferring a self-developed patent into a foreign (EU) subsidiary. As such, the judgement has contributed to eliminating tax obstacles to cross-border reorganisations from the perspective of single Member States. However, as six Member States have not adjusted their exit taxation rules by including a deferral option in the context of the National Grid Indus case, it is not possible to remove such obstacles completely across the EU. Besides, a considerable spread in cross-country EATR persists that more than doubles the spread in EATR for domestic investment $(13.23 \vee 6.25)$ due to country-specific upstream differences regarding the capitalisation of self-developed intangible assets or general availability of exit taxes.

According to Article 5 ATAD, Member States must provide for an exit taxation rule upon transfers of assets/residence to another EU Member State that allows taxpayers to settle the resulting exit tax liability in five annual instalments by 31 December 2019 (Art. 11 (5) ATAD). Although Member States may implement or maintain even stricter rules, they are bound by the "minimum level of protection" (Art. 3) established by the ATAD. Hence, countries with more generous current exit taxation rules where staggered payments are possible over a period of more than five years would have to limit the available deferral period. ${ }^{109}$ Drawing from our findings in the

109 Since Article 5 should reflect the standards on exit taxation established by ECJ case law, stricter national rules in the sense of a shorter deferral period risk being challenged on their conformity with EU law. See Peeters (2017), pp. 123 f. with reference to DG TAXUD (2016). 
above analysis of the implications of the National Grid Indus case, the length of the available deferral period was not decisive regarding the general attractiveness of the transfer of assets/residence to a low-tax Member State. However, depending on potential interrelations between the tax levels in the residence country of the transferring parent and a shortened deferral period, a limitation of the deferral period to five years might have negative repercussions for corporate relocation decisions.

\section{Conclusion}

In this paper, we have analysed the effects of four landmark rulings of the ECJ on corporate investment conditions including their impact towards the objective of realising an internal market based on effective tax levels (EATR) according to the Devereux/Griffith methodology. Following Member States' tax law amendments in the context of the Lankhorst-Hohorst and Cadbury Schweppes judgements, the treatment of domestic and cross-border investment is aligned on country level, respectively. Upon Member States' maintenance of discriminatory regulations following the Marks \& Spencer and National Grid Indus cases, by contrast, it is not possible to fully avoid discrimination of cross-border investment in line with the mandate of the ECJ. Beyond the ECJ's mandate and self-imposed goals, ${ }^{110}$ we find that Member States' heterogeneous adjustments, varying levels of compliance, differences in the general availability of rules comparable to the rule under scrutiny in a particular case as well as the impact of other national rules that remain unaffected by the judgement contribute to persistently high spreads in EATR across Member States. As such, corporate investment decisions continue to be distorted across countries which obstructs the realisation of a European internal market.

Overall, our findings seem to confirm the results of prior economic studies that cast doubts on the advantageous effects of ECJ case law on investment conditions in Member States. ${ }^{111}$ The causes that have been suggested for this overall effect are manifold: As such, it stands to reason that although tax discriminations might be avoided on country level, it is difficult to eliminate cross-country distortions and disparities upon Member States' un-coordinated tax law adjustments following a particular judgement. ${ }^{112}$ Hence, tax neutrality in terms of CEN or CIN goes beyond a mere avoidance of discrimination between domestic and cross-border investments. ${ }^{113}$

110 Although the ECJ seeks to eliminate rules that result in discrimination of cross-border investment, it does neither attempt to establish "full cross-border tax neutrality within the Internal Market" nor does it consider the general existence of differences in Member States' legal systems to violate EU law as such. See Schön (2015), p. 276 including further references.

111 See de la Feria/Fuest (2016), p. 71; Bräutigam et al. (2017), pp. $741 \mathrm{f}$.

112 See de la Feria/Fuest (2016), pp. 65-67 with further references.

113 See Spengel (2003), p. 257 who illustrates the relationship between tax neutrality concepts (CIN/CEN) and the non-discrimination principle. 
The uniform and homogeneous application of case law across Member States, however, is contingent on several factors such as "the clarity and consistency of the ECJ's judg[e]ments", "the ability of national courts to adopt and interpret" as well as "the willingness of national legislatures to adapt to, and comply with" ECJ case law. ${ }^{114}$ Based on the finding that ECJ case law does not necessarily contribute to establishing an internal market, de la Feria and Fuest (2016) even question the legitimacy of the Court's role in this regard. ${ }^{115}$

Besides, upon the transposition of case law into domestic law, Member States only selectively adjust single rules against the background of their own tax and legal systems. ${ }^{116}$ Apart from being outside the scope of the Court's mandate, the consequences of an isolated negative integration of single and in part specific rules would always fall short of the effect of full harmonisation by way of positive integration. ${ }^{117} \mathrm{Such}$ - if at all partial - harmonisation following from negative integration has further important repercussions on tax competition among Member States: In case only specific parts of European tax systems are streamlined whereas differences in other elements such as tax rates or tax bases persist, these differences subsequently become more important for investment decisions. ${ }^{118}$ Genschel et al. (2011) point to the ambiguous effects of ECJ case law on intra-EU tax competition: According to the authors, tax competition would diminish if a judgement was mainly influenced by national public interest whereas tax competition would increase upon an enhanced focus on taxpayers' free movement rights. ${ }^{119}$ Our quantitative findings lend support to this conclusion: The Lankhorst-Hohorst case, for instance, has generally facilitated cross-border (intra-group) lending. In consequence, however, tax rate competition might also intensify as lowering the overall tax burden by lending from a foreign affiliate resident in a low-tax Member State becomes a viable strategy.

To conclude, ECJ case law and Member States' associated leeway for transposing the requirements into their domestic tax laws do not seem to be an adequate instrument for eliminating tax distortions among Member States towards the realisation of an internal market, but rather only contributes to eliminating tax discriminations on country level. Besides, ECJ case law does not induce an obligation for Member States to introduce comparable (compliant) rules if such pro-

\footnotetext{
114 See Panayi (2010), p. 268 as well as - for a more detailed reasoning - pp. 297-300.

115 See de la Feria/Fuest (2016), p. 71. However, similar to the present study that analyses a small selection of landmark rulings, de la Feria/Fuest also point out that one cannot come to a reasonable general conclusion on the effects of ECJ case law based on the analysis of a single ruling.

116 See Everett (2006), p. 358.

117 See Everett (2006), p. 368.

118 See de la Feria/Fuest (2016), p. 71

119 See Genschel et al. (2011), p. 589.
} 
visions are previously unknown to the domestic tax system. To sustainably eliminate competitive distortions to investment among Member States, a comprehensive and mandatory harmonisation of direct tax systems by way of positive integration seems necessary, for instance through the introduction of a $\mathrm{C}(\mathrm{C}) \mathrm{CTB} .^{120}$

Our analysis further reveals that the effect of selective anti-abuse rules as included in the ATAD which intend to make national tax systems more resilient against tax planning strategies of multinational firms might be twofold: On the one hand, harmonised interest deduction limitation rules might lead to an overall increase in EATR which could compromise the location attractiveness of the EU as a whole. On the other hand, the harmonised and mandatory implementation of anti-abuse rules across Member States might likewise contribute to reducing the spread in EATR across Member States, for instance regarding cross-border asset relocations, and hence contribute to establishing more neutrality within the internal market.

${ }^{120}$ See Spengel (2007), p. 119; Spengel (2008), pp. 28-30; Spengel/Stutzenberger (2018), pp. 39 f. for the elimination of tax obstacles upon different degrees of tax harmonisation in the EU. 


\section{References}

Adamczyk, Ł./Majdańska, A. (2018): Chapter 1: The Sources of EU Law Relevant for Direct Taxation, in: Lang, M./Pistone, P./Schuch, J./Staringer, C. (eds.): Introduction to European Tax Law on Direct Taxation, $5^{\text {th }}$ edition, Vienna, pp. 1-33.

Aujean, M. (2010): Tax policy in the EU: between harmonisation and coordination?, in: Transfer: European Review of Labour and Research, Vol. 16 (1), pp. 11-22.

Bergner, S. (2017): Tax Incentives for Small and Medium-Sized Enterprises - A Misguided Policy Approach?, Mannheim.

Bizioli, G. (2017): Taking EU Fundamental Freedoms Seriously: Does the Anti-Tax Avoidance Directive Take Precedence over the Single Market?, in: EC Tax Review, Vol. 26 (3), pp. 167-175.

Blauberger, M. (2009): Compliance with rules of negative integration: European state aid control in the new member states, in: Journal of European Public Policy, Vol. 16 (7), pp. 1030-1046.

Blum, D. W./Langer, A. (2019): At a Crossroads: Mandatory Disclosure under DAC-6 and EU Primary Law - Part 1, in: European Taxation, Vol. 59 (6), pp. 282-290.

Bräutigam, R./Spengel, C./Streif, F. (2017): Decline of Controlled Foreign Company Rules and Rise of Intellectual Property Boxes: How the European Court of Justice Affects Tax Competition and Economic Distortions in Europe, in: Fiscal Studies, Vol. 38 (4), pp. 719-745.

Bräutigam, R./Spengel, C./Stutzenberger, K. (2019): The Development of Corporate Tax Systems in the European Union from 1998 to 2017: Qualitative and Quantitative Analysis, in: Intertax, Vol. 47 (6/7), pp. 536-562.

Brokelind, C. (2007) (ed.): Towards a Homogeneous EC Direct Tax Law: An Assessment of the Member States' Responses to the ECJ's Case Law, Amsterdam.

Cordewener, A. (2018): Cross-Border Loss Compensation and EU Fundamental Freedoms: The 'Final Losses' Doctrine Is Still Alive!, in: EC Tax Review, Vol. 27 (5), pp. 230-236.

Craig, P./de Búrca, G. (2015): EU Law: Text, cases, and materials, $6^{\text {th }}$ edition, Oxford.

Dehne, K.-J. (2018): Hinzurechnungsbesteuerung - Bestandsaufnahme und Reformbedarf, in: Internationale Steuer-Rundschau (ISR), Vol. 7 (4), pp. 132-138. 
de la Feria, R. (2009): The EU VAT System and the Internal Market, IBFD Doctoral Series, Vol. 16, Amsterdam.

de la Feria, R./Fuest, C. (2011): Closer to an Internal Market? The Economic Effects of EU Tax Jurisprudence, Oxford University Centre for Business Taxation, Working Paper 11/12, Oxford.

de la Feria, R./Fuest, C. (2016): The Economic Effects of EU Tax Jurisprudence, in: European Law Review, Vol. 41 (1), pp. 44-71.

Devereux, M. P./Griffith, R. (1999): The Taxation of Discrete Investment Choices, Institute for Fiscal Studies Working Paper Series No. W98/16 (version as of February 1999).

Devereux, M. P./Griffith, R. (2003): Evaluating Tax Policy for Location Decisions, in: International Tax and Public Finance, Vol. 10 (2), pp. 107-126.

Devereux, M. P./Loretz, S. (2008): Increased efficiency through consolidation and formula apportionment in the European Union?, Oxford University Centre for Business Taxation, Working Paper 08/12 (version as of $24^{\text {th }}$ June 2008), Oxford.

Devereux, M. P./Pearson, M. (1995): European tax harmonisation and production efficiency, in: European Economic Review, Vol. 39 (9), pp. 1657-1681.

DG TAXUD (2016): Note on the Application of the 'Minimum Level of Protection', Room Document \# 4, Working Party on Tax Questions - Direct Taxation, Anti-Tax Avoidance Directive (ATAD), 18 March 2016, available at https://www.asktheeu.org/en/request/2720/response/9485/attach/6/16\%2003\%2018\%204\%20ATAD\%20Minimum\%20Standards.pdf (accessed: 09 September 2019).

Dourado, A. P./de la Feria, R. (2008): Thin Capitalization Rules in the Context of the CCCTB, Oxford University Centre for Business Taxation, Working Paper 08/04, Oxford.

Elschner, C./Heckemeyer, J. H./Spengel, C. (2011): Besteuerungsprinzipien und effektive Unternehmenssteuerbelastungen in der Europäischen Union: Regelt sich die EU-weite Steuerharmonisierung von selbst?, in: Perspektiven der Wirtschaftspolitik, Vol. 12 (1), pp. 47-71.

European Commission (2006): Tax Treatment of Losses in Cross-Border Situations, $\operatorname{COM}(2006) 824$ final, Brussels.

European Commission (2011): Proposal for a Council Directive on a Common Consolidated Corporate Tax Base (CCCTB), COM(2011) 121/4, Brussels. 
European Commission (2016a): Proposal for a Council Directive on a Common Corporate Tax Base, COM(2016) 685 final, Strasbourg.

European Commission (2016b): Proposal for a Council Directive on a Common Consolidated Corporate Tax Base (CCCTB), COM(2016) 683 final, Strasbourg.

European Commission (2018): CJEU Cases in the Area of, or of Particular Interest for, Direct Taxation (version as of 1 April 2018), available at https://ec.europa.eu/taxation_customs/sites/taxation/files/20171116_court_cases_direct_taxation_en.pdf (accessed: 16 July 2019).

Everett, M. (2006): Der Einfluss der EuGH-Rechtsprechung auf die direkten Steuern, in: Deutsche Steuer-Zeitung (DStZ), pp. 357-369.

Evers, L. (2015): Intellectual Property (IP) Box Regimes: Tax Planning, Effective Tax Burdens, and Tax Policy Options, Mannheim.

Evers, L./Miller, H./Spengel. C. (2015): Intellectual property box regimes: effective tax rates and tax policy considerations, in: International Tax and Public Finance, Vol. 22 (3), pp. 502-530.

Evers, L./Spengel, C. (2014): Effective Tax Rates under IP Tax Planning, ZEW Discussion Paper No. 14-111, Mannheim.

Genschel, P./Kemmerling, A./Seils, E. (2011): Accelerating Downhill: How the EU Shapes Corporate Tax Competition in the Single Market, in: Journal of Common Market Studies, Vol. 49 (3), pp. 585-606.

Gusmeroli, M./Russo, M. (2004): Italian Thin Capitalization Rules, Tax Treaties and EC Law: Much Ado About Something, in: Intertax, Vol. 32 (10), pp. 493-519.

Gutmann, D./Hinnekens, L. (2003): The Lankhorst-Hohorst case. The ECJ finds German thin capitalization rules incompatible with freedom of establishment, in: EC Tax Review, Vol. 12 (2), pp. 90-97.

Gutmann, D./Perdelwitz, A./Raingeard de la Blétière, E./Offermanns, R./Schellekens, M./Gallo, G./Grant Hap, A./Olejnicka, M. (2017); The Impact of the ATAD on Domestic Systems: A Comparative Survey, in: European Taxation, Vol. 57 (1), pp. 2-20.

Hintsanen, L./Pettersson, K. (2005): The Implications of the ECJ Holding the Denial of Finnish Imputation Credits in Cross-Border Situations to Be Incompatible with the EC Treaty in the Manninen Case, in: European Taxation, Vol. 45 (4), pp. 130-137. 
Koerver Schmidt, P. (2013): Denmark - Branch report, in: International Fiscal Association: The taxation of foreign passive income for groups of companies, $67^{\text {th }}$ Congress of the International Fiscal Association (Copenhagen), cahiers de droit fiscal international, Vol. 98a, The Hague, pp. 259-277.

Koerver Schmidt, P. (2014): Are the Danish CFC Rules in Conflict with the Freedom of Establishment? - An Analysis of the Danish CFC Regime for Companies in Light of ECJ Case Law, in: European Taxation, Vol. 54 (1), pp. 3-9.

Koury, P. A. C. (2018): The End of the "Luxembourg Effect": An Analysis of the Protection of Fundamental Freedoms Regarding Exit Taxes and Implementation of Anti-BEPS Measures by the European Union, in: European Taxation, Vol. 58 (11), pp. 505-512.

Kraft, G. (2018): Praktische Implikationen der Neupositionierung der EuGH-Rechtsprechung zur Rechtsfigur „finaler Verluste”, in: NWB - Steuer- und Wirtschaftsrecht, Vol. 2018 (33), pp. 2384-2392.

Kube, H./Reimer, E./Spengel, C. (2016): Tax Policy: Trends in the Allocation of Powers Between the Union and Its Member States, in: EC Tax Review, Vol. 25 (5/6), pp. 247-261.

Lammersen, L. (2005): Steuerbelastungsvergleiche: Anwendungsfelder und Grenzen in der Steuerplanung und der Steuerwirkungslehre, Wiesbaden.

Lang, M. (2005): Ist die Schumacker-Rechtsprechung am Ende? Die Verpflichtung zur Berücksichtigung der persönlichen Verhältnisse und des Familienstandes in einem der Mitgliedstaaten, in: Recht der Internationalen Wirtschaft (RIW), Vol. 51 (5), pp. 336-344.

Lang, M. (2006): The Marks \& Spencer Case - The Open Issues Following the ECJ's Final Word, in: European Taxation, Vol. 46 (2), pp. 54-67.

Lang, M. (2014): Has the Case Law of the ECJ on Final Losses Reached the End of the Line?, in: European Taxation, Vol. 54 (12), pp. 530-540.

Lazarov, I. (2018): Chapter 3 - The Relevance of the Fundamental Freedoms for Direct Taxation, in: Lang, M./Pistone, P./Schuch, J./Staringer, C. (eds.): Introduction to European Tax Law on Direct Taxation, $5^{\text {th }}$ edition, Vienna, pp. 61-101.

Meussen, G. T. K. (2007): Cadbury Schweppes: The ECJ Significantly Limits the Application of CFC Rules in the Member States, in: European Taxation, Vol. 47 (1), pp. 13-18. 
Olbert, M./Spengel, C./Werner, A. (2019): Measuring and Interpreting Countries ‘ Tax Attractiveness for Investments in Digital Business Models, in: Intertax, Vol. 47 (2), pp. 148160.

Panayi, C. HJI (2010): Reverse Subsidiarity and EU Tax Law: Can Member States be Left to their Own Devices?, in: British Tax Review, No. 3, pp. 267-301.

Peeters, S. (2017): Exit Taxation: From an Internal Market Barrier to a Tax Avoidance Prevention Tool, in: EC Tax Review, Vol. 26 (3), pp.

Pfeiffer, O./Spengel, C. (2017): Tax Incentives for Research and Development and Their Use in Tax Planning, ZEW Discussion Paper No. 17-046, Mannheim.

Pinder, J. (1968): Positive integration and negative integration: Some problems of economic union in the EEC, in: The World Today, Vol. 24 (3), pp. 88-110.

Rossi, M. (2005): Italy's Thin Capitalization Rules, in: Tax Notes International, Vol. 40 (1), pp. 89-101.

Ruf, M./Weichenrieder, A. J. (2012): The taxation of passive foreign investment: lessons from German experience, in: The Canadian Journal of Economics / Revue canadienne d'Economique, Vol. 45 (4), pp. 1504-1528.

Ruf, M./Weichenrieder, A. J. (2013): CFC Legislation, Passive Assets and the Impact of the ECJ's Cadbury-Schweppes Decision, CESifo Working Paper No. 4461.

Schaper, M. G. H. (2014a): 30 Years of Direct Tax Litigation before the Court of Justice of the European Union: An Empirical Survey, in: Bulletin for International Taxation, Vol. 68 (4/5), pp. 236-249.

Schaper, M. G. H. (2014b): A Computational Legal Analysis of Acte Clair Rules of EU Law in the Field of Direct Taxes, in: World Tax Journal, Vol. 6 (1), pp. 77-108.

Scharpf, F. W. (1994): Mehrebenenpolitik im vollendeten Binnenmarkt, in: Staatswissenschaften und Staatspraxis: rechts-, wirtschafts- und sozialwissenschaftliche Beiträge zum staatlichen Handeln, Vol. 5, pp. 475-501.

Scharpf, F. (1998): Negative and Positive Integration in the Political Economy of European Welfare States, in: Rhodes, M. (ed.), The future of European welfare: a new social contract?, London, pp. 157-177.

Scharpf, F. W. (2006): The Joint-Decision Trap Revisited, in: Journal of Common Market Studies, Vol. 44 (4), pp. 845-864. 
Schmidt, S. K. (2008): Beyond Compliance: The Europeanization of Member States through Negative Integration and Legal Uncertainty, in: Journal of Comparative Policy Analysis, Vol. 10 (3), pp. 299-308.

Schön, W. (2015): Neutrality and Territoriality - Competing or Converging Concepts in European Tax Law?, in: Bulletin for International Taxation, Vol. 69 (4/5), pp. 271-293.

Schönfeld, J. (2017): CFC Rules and Anti-Tax Avoidance Directive, in: EC Tax Review, Vol. 26 (3), pp. 145-152.

Schreiber, U./Führich, G. (2009): European group taxation - the role of exit taxes, in: European Journal of Law and Economics, Vol. 27 (3), pp. 257-274.

Seiler, C. (2005): Das Steuerrecht unter dem Einfluss der Marktfreiheiten, in: Steuer und Wirtschaft (StuW), pp. 25-36.

Sendetska, O. (2014): ECJ Case Law on Corporate Exit Taxation: From National Grid Indus to DMC: What is the Current State of Law?, in: EC Tax Review, Vol. 23 (4), pp. 230-237.

Spengel, C. (2003): Internationale Unternehmensbesteuerung in der Europäischen Union: Steuerwirkungsanalyse - Empirische Befunde - Reformüberlegungen, Düsseldorf.

Spengel, C. (2007): Common corporate consolidated tax base - don't forget the tax rates!, in: EC Tax Review, Vol. 16 (3), pp. 118-120.

Spengel, C. (2008): Concept and Necessity of a Common Tax Base - an academic introduction, in: Schön, W./Schreiber, U./Spengel, C. (eds.), A Common Consolidated Corporate Tax Base for Europe, Berlin/Heidelberg, pp. 1-47.

Spengel, C./Bergner, S. (2015): Investitionswirkungen der deutschen Unternehmensbesteuerung im internationalen Vergleich: Eine Analyse vor dem Hintergrund der Steuerreformen 2001 und 2008 unter Berücksichtigung grenzüberschreitender Investitionen. Expertise für den Sachverständigenrat zur Begutachtung der gesamtwirtschaftlichen Entwicklung, Mannheim.

Spengel, C./Heckemeyer, J. H./Nicolay, K./Bräutigam, R./Klar, O./Stutzenberger, K. (2016c): The Effects of Tax Reforms to Address the Debt-Equity Bias on the Cost of Capital and on Effective Tax Rates, European Commission Taxation Papers, Working Paper N. 652016, Luxembourg.

Spengel, C./Heckemeyer, J. H./Nicolay, K./Bräutigam, R./Stutzenberger, K. (2018a): Addressing the Debt-Equity Bias within a Common Consolidated Corporate Tax Base (CCCTB) 
- Possibilities, Impact on Effective Tax Rates and Revenue Neutrality, in: World Tax Journal, Vol. 10 (2), pp. 165-191.

Spengel, C./Heckemeyer, J. H./Nusser, H./Klar, O./Streif, F. (2016b): The Impact of Tax Planning on Forward-Looking Effective Tax Rates, European Commission Taxation Papers, Working Paper N. 64-2016, Luxembourg.

Spengel, C./Heckemeyer, J. H./Streif, F. (2016a): The Effect of Inflation and Interest Rates on Forward-Looking Effective Tax Rates, European Commission Taxation Papers, Working Paper N. 63-2016, Luxembourg.

Spengel, C./Nicolay, K./Werner, A./Olbert, M./Steinbrenner, D./Schmidt, F./Wolf, T. (2018b): Steuerliche Standortattraktivität digitaler Geschäftsmodelle: Steuerlicher Digitalisierungsindex 2018, Frankfurt/Mannheim.

Spengel, C./Stutzenberger, K. (2018): Widersprüche zwischen Anti-Tax Avoidance Directive (ATAD), länderbezogenem Berichtswesen (CbCR) und Wiederauflage einer Gemeinsamen (Konsolidierten) Körperschaftsteuer-Bemessungsgrundlage (GK(K)B), in: Internationales Steuerrecht (IStR), Vol. 27 (2), pp. 37-44.

Terra, B. J. M./Wattel, P. J. (2012): European Tax Law, $6^{\text {th }}$ edition, Alphen aan den Rijn.

Tinbergen, J. (1965): International Economic Integration, $2^{\text {nd }}$ edition, Amsterdam.

Thoemmes, O./Stricof, R./Nakhai, K. (2004): Thin Capitalization Rules and Non-Discrimination Principles - An analysis of thin capitalization rules in the light of the non-discrimination principle in the EC Treaty, double tax treaties and friendship treaties, in: Intertax, Vol. 32 (3), pp. 126-137.

Vinther, N./Werlauff, E. (2003): The need for fresh thinking about tax rules on thin capitalization: the consequences of the judgement of the ECJ in Lankhorst-Hohorst, in: EC Tax Review, Vol. 12 (2), pp. 97-106.

ZEW (2018): Effective Tax Levels Using the Devereux/Griffith Methodology, Project for the EU Commission, TAXUD/2018/DE/307, Intermediary Report 2018 (October 2018), Mannheim. 


\section{Appendix}

\section{A.1. The basic formulas of the Devereux/Griffith model}

The EATR is used as a measure to estimate the impact of ECJ case law on investment location decisions and its contribution towards the establishment of an internal market. It is computed as the difference of net present value (NPV) before and after taxes (denoted by $R^{*}$ and $R$ ), divided by the discounted pre-tax rate of return $p$ :

(1) $E A T R=\frac{R^{*}-R}{p /(1+r)}$ with

(2) $R^{*}=\frac{p-r}{1+r}$ and

(3) $R=-\gamma *(1-A+e)+\frac{\gamma}{1+\rho} *[(p+\delta) *(1+\pi) *(1-\tau)+(1-\delta) *(1+\pi) *$ $(1-A)] \cdot{ }^{121}$

For financing possibilities other than retained earnings, $R$ must be modified by an additional financing term $F$ as established in Table A1: ${ }^{122}$

Table A1: Financing terms in the Devereux/Griffith model

\begin{tabular}{|ll|}
\hline Retained earnings $(R E)$ & (4) $F^{R E}=0$ \\
\hline New equity $(N E)$ & (5) $F^{N E}=-\frac{\rho *(1-\gamma) *(1+e)}{1+\rho}$ \\
\hline $\operatorname{Debt}(D)$ & (6) $F^{D}=\frac{\gamma *(1+e) *(\rho-i *(1-\beta * \tau))}{1+\rho} 123$ \\
\hline
\end{tabular}

In the absence of personal taxes, the shareholder's nominal discount rate $\rho$ equals the nominal interest rate $i$. Otherwise, it is defined as:

(7) $\rho=\left(\frac{1-m^{i}}{1-z}\right) * i .^{124}$

121 The term $e$ has been included in the standard formulas to account for non-profit taxes such as real estate or net wealth taxes. $\tau$ is the effective corporate income tax rate whereas $A$ reflects the present value of depreciation allowances according to national tax laws, $\delta$ accounts for the true economic depreciation rate and $\gamma$ denotes the tax discrimination between new equity and profit distributions. $\pi$ reflects the inflation rate.

${ }^{122}$ Further modification is necessary if a Member State offers a notional interest deduction (NID), see Evers (2015), pp. 98 f.; ZEW (2018), p. B-26.

$123 \beta$ represents the fraction of tax-deductible interest at corporate level.

124 See ZEW (2018), p. B-2. $m^{i}$ describes the taxation of interest income at shareholder level whereas $z$ is the effective capital gains tax. 
The investment and financing structure of the domestic model is illustrated in Figure A1.

Figure A1: Structure of domestic investment

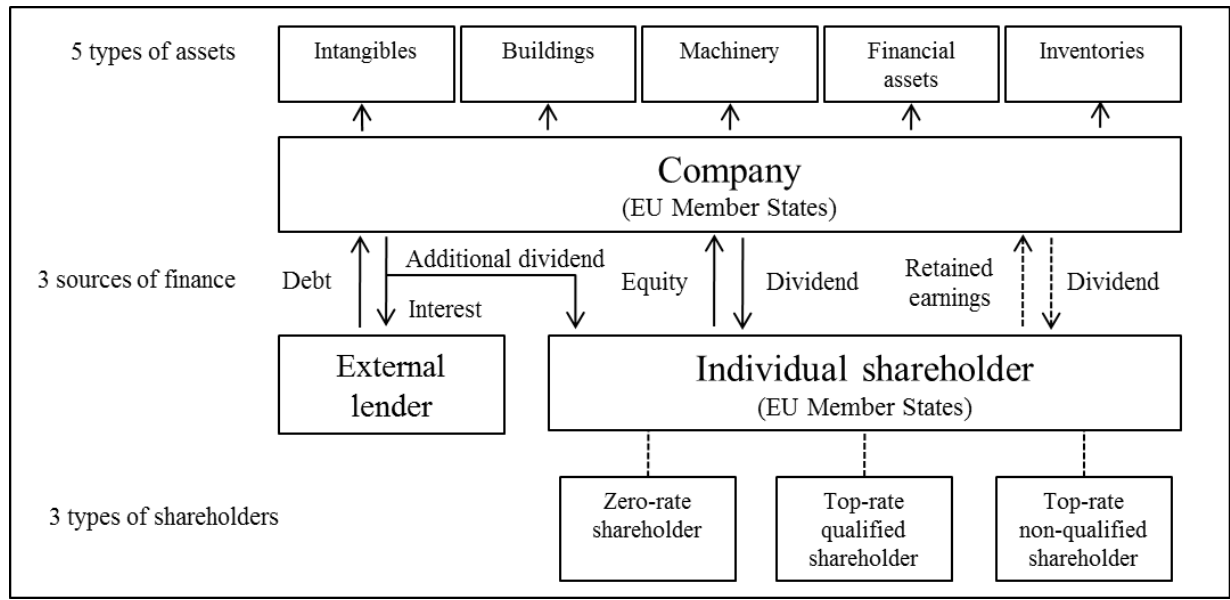

Apart from country-specific information on the type of tax system, types of applicable taxes (profit/non-profit), tax bases and tax rates on company and investor level, ${ }^{125}$ the model rests on certain economic assumptions set out in Table A2.

\section{Table A2: Economic assumptions of the Devereux/Griffith model}

\begin{tabular}{|c|c|c|c|}
\hline \multicolumn{4}{|c|}{ Assumptions on types of taxes and tax bases } \\
\hline Company level & \multicolumn{3}{|c|}{$\begin{array}{l}\text { Corporate income tax including surcharges, local business taxes, non- } \\
\text { profit taxes }\end{array}$} \\
\hline Investor level & \multicolumn{3}{|c|}{ Personal income tax, wealth tax, surcharges } \\
\hline Tax base & \multicolumn{3}{|c|}{ Depreciation, inventory valuation, deductibility of interest expenses } \\
\hline Types of assets & \multicolumn{3}{|c|}{ Intangibles, buildings, machinery, financial assets, inventory } \\
\hline \multicolumn{4}{|c|}{ Assumptions on assets, financing and investors } \\
\hline Financing & \multicolumn{3}{|c|}{ Self-financing (retained earnings), new equity financing, debt financing } \\
\hline Investors & \multicolumn{3}{|c|}{$\begin{array}{l}\text { Top marginal statutory tax rate (qualified and non-qualified holding), zero } \\
\text { tax rate }\end{array}$} \\
\hline $\begin{array}{l}\text { Weights for assets, investors } \\
\text { and financing }\end{array}$ & \multicolumn{3}{|c|}{$\begin{array}{ll}- & \text { Assets: proportional }(20 \% \text { each) } \\
\text { - } & \text { Investors: proportional }(33.33 \% \text { each) } \\
- & \text { Financing: } 55 \% \text { self-financing, } 10 \% \text { new equity financing, } 35 \% \text { debt } \\
\text { financing }\end{array}$} \\
\hline \multicolumn{4}{|c|}{ Assumptions on depreciation, inflation, interest rate and pre-tax rate of return } \\
\hline Economic depreciation period & $\begin{array}{l}\text { Intangibles: } \\
12.5 \text { years }\end{array}$ & $\begin{array}{l}\text { Buildings: } \\
53 \text { years }\end{array}$ & $\begin{array}{l}\text { Machinery: } \\
11 \text { years }\end{array}$ \\
\hline Inflation rate $(\pi)$ & \multicolumn{3}{|c|}{$2 \%$} \\
\hline Real interest rate $(r)$ & \multicolumn{3}{|c|}{$5 \%$} \\
\hline Nominal interest rate $(i)$ & \multicolumn{3}{|c|}{$7.1 \%$} \\
\hline Pre-tax rate of return $(p)$ & \multicolumn{3}{|c|}{$20 \%$} \\
\hline
\end{tabular}

Source: Spengel (2003), p. 88.

125 As indicated by the annual update on effective tax levels in the EU; see ZEW (2018). 
To analyse cross-border investments, an extension of the baseline model framework is necessary (see Figure A2). ${ }^{126}$ In the cross-border case, it is assumed that the investment is undertaken by a wholly owned foreign subsidiary which can be financed by retained earnings, new equity or debt. Whereas the asset structure and financing of the parent entity remain unchanged in relation to the domestic case, the different financing alternatives of the subsidiary are weighted proportionately (33.33\% each). Furthermore, the calculations must consider the rules for foreign business activities applicable in the residence state of the parent company as well as relevant provisions from bilateral double tax conventions, for instance regarding source taxes or the method for avoiding double taxation of capital income.

Figure A2: Structure of cross-border investment

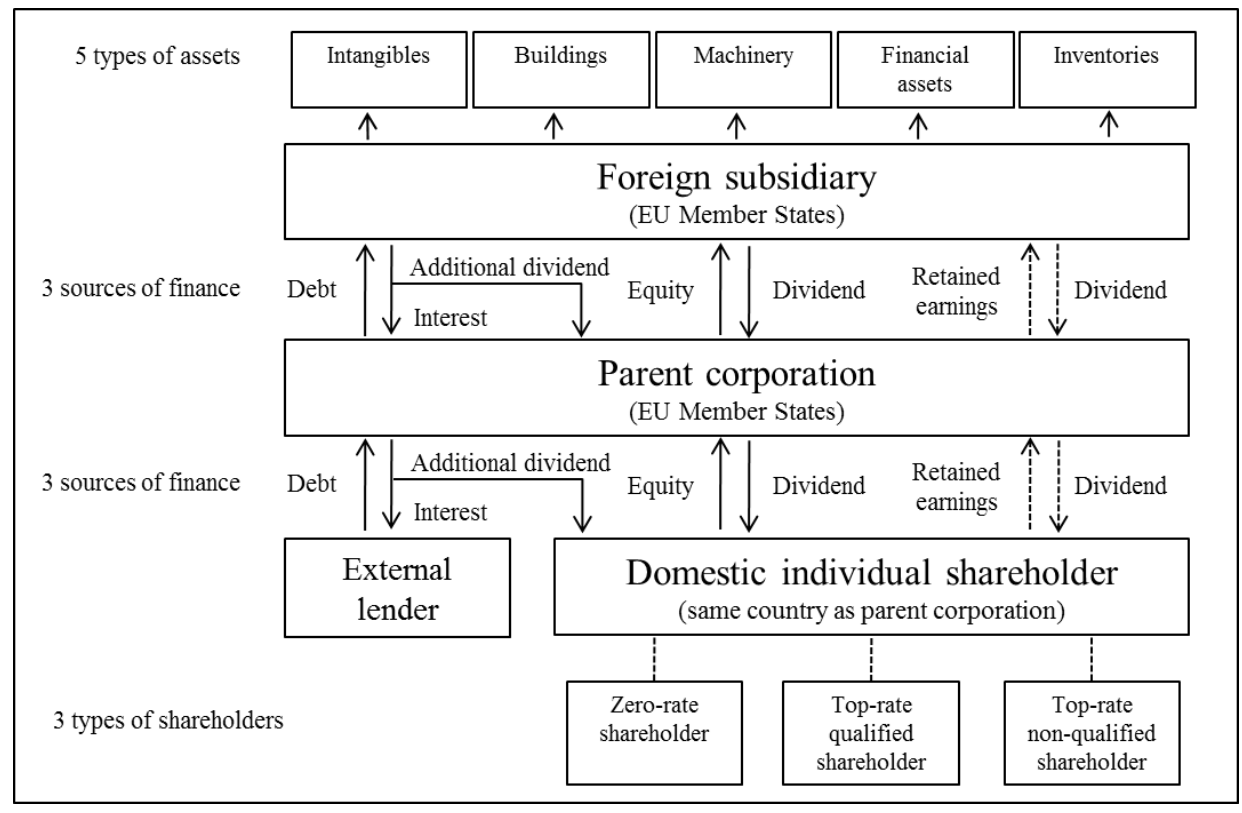

\section{A.2. Amendments of the basic formulas of the Devereux/Griffith model}

\section{A.2.1. Amendments regarding the "Lankhorst-Hohorst" Case}

To quantify the impact of the Lankhorst-Hohorst case on effective tax rates of corporations located in different Member States within the Devereux/Griffith model, we follow the (slightly modified) approach of Spengel et al. (2016c) and consider a 100\% debt-financed investment (corporate level only). ${ }^{127}$ In general, different approaches to limit the deductibility of interest expenses exist: Member States can either restrict interest deductibility with reference to a profit

${ }^{126}$ For a detailed explanation of the extension and underlying formulas, see Devereux/Griffith (1999), pp. 24-30, 40-46; Spengel (2003), pp. 134-138; Lammersen (2005), pp. 250-256.

127 The lender itself is refinanced in line with the standard assumptions of the Devereux/Griffith methodology (55\% retained earnings, $10 \%$ new equity, $35 \%$ debt). See also Spengel et al. (2016c), p. 29 for the following description of the methodology and underlying assumptions. 
measure (so-called earnings-strippings rules), a fixed ratio of balance sheet positions (e.g. debt/equity or debt/assets) or based on the arm's length approach. As the Devereux/Griffith model does not specify the characteristics of the underlying company in terms of balance sheet positions or profit measures and further assumes that a third party provides debt under arm's length conditions, it is impossible to model specific characteristics of interest deduction limitation rules or even rules that target only related party debt. Therefore, in case a Member State restricts the deductibility of domestic and/or cross-border interest payments by whichever rule, we assume that such rules fully inhibit interest deductibility and adjust $\beta$ in equation (6) accordingly (i.e. $\beta=0$ ). If full interest deductibility is available, in contrast, it holds that $\beta=1$. $^{128}$

\section{A.2.2. Amendments regarding the "Marks \& Spencer" Case}

Devereux and Loretz (2008) have already introduced an international loss consolidation mechanism within the Devereux/Griffith framework. ${ }^{129}$ In line with the standard model, the authors assume that a parent company finances an investment of its wholly owned foreign subsidiary. They assign different probabilities to a "good" outcome where the subsidiary's investment is profitable as well as to a "bad" outcome where investment yields a negative return to evaluate the implications of international loss consolidation and formulary apportionment for the efficiency of the EU tax system. Against the background of a new subsidiary that does not have any retained or current profits, the loss of the subsidiary corresponds to the depreciation allowance in period $t$.

In contrast, we assume that the parent company splits its investment into a domestic investment in its residence state (weighted by $w_{p}$ ) and a cross-border investment through its foreign subsidiary (weighted by $w_{s}$ with $w_{p}+w_{s}=1$ ). The parent company's domestic investment yields a positive pre-tax rate of return, depicted as $p_{p}$, whereas the return is negative for the subsidiary's investment $(l<0)$. By assumption, the subsidiary's loss is equal to $-5 \%$ whereas the investments of the parent and subsidiary are weighted by $80 \%$ and $20 \%$, respectively. To keep the investments' overall profitability $p$ constant at $20 \%$ in line with the general Devereux/Griffith methodology, we adjust the pre-tax profitability of the parent's domestic investment $\left(p_{p}\right)$ to $26.25 \%$.

\footnotetext{
128 Other than Spengel et al. (2016c), we do not adjust $\beta$ further to reflect the value of an interest carry-forward since no country under consideration introduced such a provision as an immediate consequence of the Lankhorst-Hohorst case.

129 See Devereux/Loretz (2008), pp. 6-11.
} 
It hence holds that:

(8) $p=w_{p} * p_{p}+w_{s} * l$.

It is further necessary to adjust both the pre-tax return $R^{*}$ and the return after taxes $R$ for cases with and without group-wide (international) loss consolidation. Under the split investment and in the presence of losses, we adjust the pre-tax return to:

(9) $R_{\text {split }}^{*}=\frac{\left(w_{p} * p_{p}+w_{s} * l\right)-r}{1+r}$.

In case intra-group loss compensation is available, the taxable income of the parent entity is reduced due to the loss-making investment of the subsidiary. It follows that: ${ }^{130}$

$$
\begin{aligned}
& \text { (10) } R_{\text {split }}^{\text {cons }}=-(1-A) * w_{p}+\left(\frac{1}{1+i}\right) *\left[\left(w_{p} * p_{p}+w_{s} * l+w_{p} * \delta\right) *(1+\pi) *(1-\tau)+w_{p} *\right. \\
& (1-\delta) *(1+\pi) *(1-A)] .
\end{aligned}
$$

Without such consolidation mechanism, no comparable tax relief is granted to the parent entity, however it has to bear the final loss of its affiliate which leads to:

$$
\begin{aligned}
& \text { (11) } R_{\text {split }}^{\text {no cons }}=-(1-A) * w_{p}+\left(\frac{w_{p}}{1+i}\right) *\left[\left(p_{p}+\delta\right) *(1+\pi) *(1-\tau)+(1-\delta) *\right. \\
& (1+\pi) *(1-A)]+\frac{w_{s} * l *(1+\pi)}{1+i}
\end{aligned}
$$

Altogether, to evaluate the impact of the Marks \& Spencer case on the establishment of an internal market, the amended EATR is represented as:

(12) $E A T R=\frac{R_{\text {split }}^{*}-R_{\text {split }}^{\text {cons } / \text { o cons }}}{\frac{\left(w_{p}^{*} p_{p}+w_{S^{*}}\right)}{1+r}}$.

\section{A.2.3. Amendments regarding the "Cadbury Schweppes" Case}

To analyse the impact of the Cadbury Schweppes case on investment conditions in the internal market, we follow the general approach of Bräutigam et al. (2017) and assume a cross-border investment of a parent company situated in one Member State that invests into a subsidiary located in any other Member State.

${ }^{130}$ For simplicity, we do not consider non-profit taxes in the loss scenario. Such taxes would only be decisive at the level of the loss-making affiliate since they might induce substance taxation. However, as we consider a fixed amount of final losses, there is no further distinction on the composition of such losses. At parent level, non-profit taxes would not add value to the considerations and rather merely scale the results. 
The EATR for a cross-border investment under the consideration of CFC rules is defined as: ${ }^{131}$

(13) $E A T R_{\text {cross-border }}^{C F C}=\left\{\begin{array}{c}E A T R_{\text {cross-border }} \text { if } E A T R_{\text {domestic }}^{\text {subsidiary }} \geq E A T R_{\text {domestic }}^{\text {parent }} * \text { Threshold } \\ E A T R_{\text {domestic }}^{\text {parent }} \text { if } E A T R_{\text {domestic }}^{\text {subsidiary }}<E A T R_{\text {domestic }}^{\text {parent }} * \text { Threshold }\end{array}\right.$.

In line with Bräutigam et al. (2017), we assume that the parent company finances its subsidiary by $100 \%$ new equity and is itself re-financed by $100 \%$ new equity. ${ }^{132}$ In contrast, however, we do not include potential (detrimental) second-round effects for intra-EU tax competition such as the increased implementation of patent box regimes, but merely focus on the immediate consequences of the Cadbury Schweppes case on Member States' tax systems. Besides, Bräutigam et al. (2017) apply a strict specification for the applicability of CFC rules and disregard Member States that follow the so-called jurisdictional approach for determining low-tax jurisdictions upon official black- or whitelists in their main analysis. ${ }^{133}$ In contrast, we do not distinguish the approaches of the underlying CFC rules.

\section{A.2.4. Amendments regarding the "National Grid Indus" Case}

To evaluate if the National Grid Indus case has contributed to a reduction of tax distortions in the internal market, we build on the approach of Evers and Spengel (2014) and consider the transfer of a self-created patent from the parent company to its foreign subsidiary. ${ }^{134}$

As displayed in Table A3, we consider four possible scenarios in our analysis:

Table A3: Overview of amendments regarding the "National Grid Indus" case

\begin{tabular}{|l|c|c|c|}
\hline & Exit taxation & No exit taxation & Comparison with \\
\hline $\begin{array}{l}\text { No capitalisation of } \\
\text { self-created patent }\end{array}$ & {$[1] R_{e x}$} & {$[3] R_{\text {no ex }}$} & $R_{\text {dom }}$ \\
\hline $\begin{array}{l}\text { Capitalisation of } \\
\text { self-created patent }\end{array}$ & {$[2] R_{\text {ex,cap }}$} & {$[4] R_{\text {no ex }, \text { cap }}$} & $R_{\text {dom,cap }}$ \\
\hline Adjustment of A & $A_{S L, S}^{T P}$ & $A_{s, \text { no ex }}^{T P}$ & \\
\hline
\end{tabular}

131 For a detailed explanation and derivation of the formula, see Bräutigam et al. (2017), pp. $730 \mathrm{f}$.

132 See Bräutigam et al. (2017), p. 730. We benchmark the outcome of the cross-border investment against a domestic investment of the parent corporation that is likewise financed by $100 \%$ new equity.

133 See Bräutigam et al. (2017), pp. 726, 740.

134 The following description is based on and adapted from Evers/Spengel (2014), pp. 11-17 and Evers (2015), pp. 126-130 including detailed derivations of the formulas and explanations as well as further references. 
In the first two scenarios, the Member State of the domestic parent imposes exit taxes on the transfer of patents. The amount of exit taxes is determined by the underlying transfer price $T P$ that - by assumption - corresponds to the earnings value $(E V)$ of the patent: ${ }^{135}$

(14) $E V=(p+\delta) * \frac{(1+\pi)}{i+\delta(1+\pi)-\pi}$.

Furthermore, the return from the exploitation of the patent is subject to tax under the rules of the Member State where the recipient resides. Upon straight-line depreciation at a periodical rate of $\varphi_{s}$ over the patent's useful life $(u l)$, the present value of depreciation allowances in scenario 1 and 2 can be depicted as: ${ }^{136}$

(15) $A_{S L, S}^{T P}=\tau_{s} * T P * \varphi_{S} *\left(\frac{1}{(1+i)^{1}}+\cdots+\frac{1}{(1+i)^{u l}}\right)=\tau_{S} * T P * \frac{\varphi_{S}}{i}\left(1-\frac{1}{(1+i)^{u l}}\right)$ with

(16) $u l=\frac{1}{\varphi_{s}}$.

In contrast to the second scenario, self-developed patents cannot be capitalised for tax purposes according to Member States national tax law in the first scenario and hence have a book value of zero. ${ }^{137}$ Thus, R\&D costs are expensed immediately $\left(\varphi_{0}=100 \%\right)$ and shield part of the return from taxation at the level of the parent entity (expressed as $\left.\varphi_{0} * \tau_{p}\right) .{ }^{138}$

Taken together, when considering the transfer of a non-capitalised patent, exit taxation and the exploitation of a patent by the subsidiary, ${ }^{139}$ the standard return after taxes in the Devereux/Griffith formula is modified to: ${ }^{140}$

(17) $R_{e x}=-\left(1-\varphi_{0} \tau_{p}-A_{s}^{T P}\right)-\left(\tau_{p} * T P\right)+\frac{(p+\delta) *(1+\pi)}{1+i} *\left(1-\tau_{s}\right)+\frac{\left(1-\varphi_{0} \tau_{p}-A_{S}^{T P}+\tau_{p} T P\right) *(1-\delta) *(1+\pi)}{1+i}$.

In the second scenario, national tax law of the transferring entity's residence state requires the capitalisation of the patent. Therefore, only the difference between the transfer price and the book value is subject to exit tax. In this scenario, the book value of the patent corresponds to

135 See Evers/Spengel (2014), pp. 14-16; Evers (2015), pp. 128 f.

136 See Evers/Spengel (2014), p. 13; Evers (2015), p. 127.

137 In Cyprus, Portugal and Sweden, however, the capitalisation of self-developed patents is mandatory. In Slovenia, research costs cannot be capitalised whereas domestic law stipulates the capitalisation of development costs. Yet, we assume that there is no capitalisation of the patent in Slovenia and all related costs are immediately expensed for the quantitative analysis in Section 7.3.

138 See Evers/Spengel (2014), p. 6; Evers et al. (2015), pp. 511 f.; Evers (2015), pp. 96 f.

139 Within the two-period framework of the Devereux/Griffith model, the transfer takes place in the same period as the R\&D investment and creation of the patent. See Evers/Spengel (2014), p. 12; Evers (2015), p. 127.

140 See Evers/Spengel (2014), p. 11; Evers (2015), p. 126. 
the costs of creating the patent (i.e. 1). This extends the formulas established by Evers and Spengel (2014) as follows:

(18) $R_{\text {ex,cap }}=-\left(1-A_{s}^{T P}\right)-\tau_{p} *(T P-1)+\frac{(p+\delta) *(1+\pi) *\left(1-\tau_{s}\right)}{1+i}+\frac{\left(1-A_{S}^{T P}+\tau_{p} *(T P-1)\right) *(1-\delta) *(1+\pi)}{1+i}$.

To ensure consistency, we additionally account for a "step-up" in the value of the patent to the earnings value (i.e. the transfer price) in case the transferring entity is subject to exit taxes in its residence state.

To account for a staggered recovery of exit taxes in the residence country of the parent entity over a period of $T_{d e f}$, we extend the formula proposed by Evers and Spengel (2014) as follows:

(19) Deferral $\left(\tau_{p} * T P\right)=\frac{1}{T_{\text {def }}} *\left(\frac{1}{1+i}+\cdots+\frac{1}{(1+i)^{T} \text { def }}\right) * \tau_{p} * T P *(1+\pi)=\frac{\tau_{p} * T P *(1+\pi)}{T_{\text {def }}} * \frac{1}{i} *\left(1-\frac{1}{(1+i)^{T} \text { def }}\right)$.

In scenario 3 and 4, no exit taxes are imposed by the transferring entity's residence state. Hence, the foreign subsidiary capitalises the patent based on its costs at a value of 1 without an eligible step-up. Equations (20) and (21) reflect the after-tax return if no exit taxes are levied for the cases of immediate deduction and capitalisation of R\&D costs, respectively.

(20) $R_{\text {no ex }}=-\left(1-\varphi_{0} \tau_{p}-A_{s, \text { no ex }}^{T P}\right)+\frac{(p+\delta) *(1+\pi) *\left(1-\tau_{s}\right)}{1+i}+\frac{\left(1-\varphi_{0} \tau_{p}-A_{S, \text { no ex }}^{T P}\right) *(1-\delta) *(1+\pi)}{1+i}$;

(21) $R_{\text {no ex,cap }}=-\left(1-A_{s, \text { no ex }}^{T P}\right)+\frac{(p+\delta) *(1+\pi) *\left(1-\tau_{s}\right)}{1+i}+\frac{\left(1-A_{S, n o \text { ex }}^{T P}\right) *(1-\delta) *(1+\pi)}{1+i}$.

In both cases, equation (15) must be adjusted:

(22) $A_{s, \text { no ex }}^{T P}=\tau_{s} * 1 * \frac{\varphi_{s}}{i} *\left(1-\frac{1}{(1+i)^{u l}}\right)$.

As a benchmark, we compare the cross-border transfer of the patent to a purely domestic situation. If the patent is not capitalised under the laws of the Member State where the parent entity is resident, the return after taxes is calculated as:

(23) $R_{\text {dom }}=-\left(1-\varphi_{0} \tau_{p}\right)+\frac{(p+\delta) *(1+\pi) *\left(1-\tau_{p}\right)}{1+i}+\frac{\left(1-\varphi_{0}\right) *(1-\delta) *(1+\pi)}{1+i}$.

In turn, if $R \& D$ costs must be capitalised, the patent is depreciated according to domestic rules and the after-tax return is equal to:

(24) $R_{\text {dom,cap }}=-\left(1-A_{p}\right)+\frac{(p+\delta) *(1+\pi) *\left(1-\tau_{p}\right)}{1+i}+\frac{\left(1-A_{p}\right) *(1-\delta) *(1+\pi)}{1+i}$. 
Download ZEW Discussion Papers from our ftp server:

http://ftp.zew.de/pub/zew-docs/dp/

or see:

https://www.ssrn.com/link/ZEW-Ctr-Euro-Econ-Research.html

https://ideas.repec.org/s/zbw/zewdip.html

$$
\text { / / }
$$

ZEW - Leibniz-Zentrum für Europäische Wirtschaftsforschung GmbH Mannheim

ZEW - Leibniz Centre for European

Economic Research

L 7,1 68161 Mannheim · Germany

Phone +49621 1235-01

info@zew.de.zew.de

Discussion Papers are intended to make results of ZEW research promptly available to other economists in order to encourage discussion and suggestions for revisions. The authors are solely responsible for the contents which do not necessarily represent the opinion of the ZEW. 